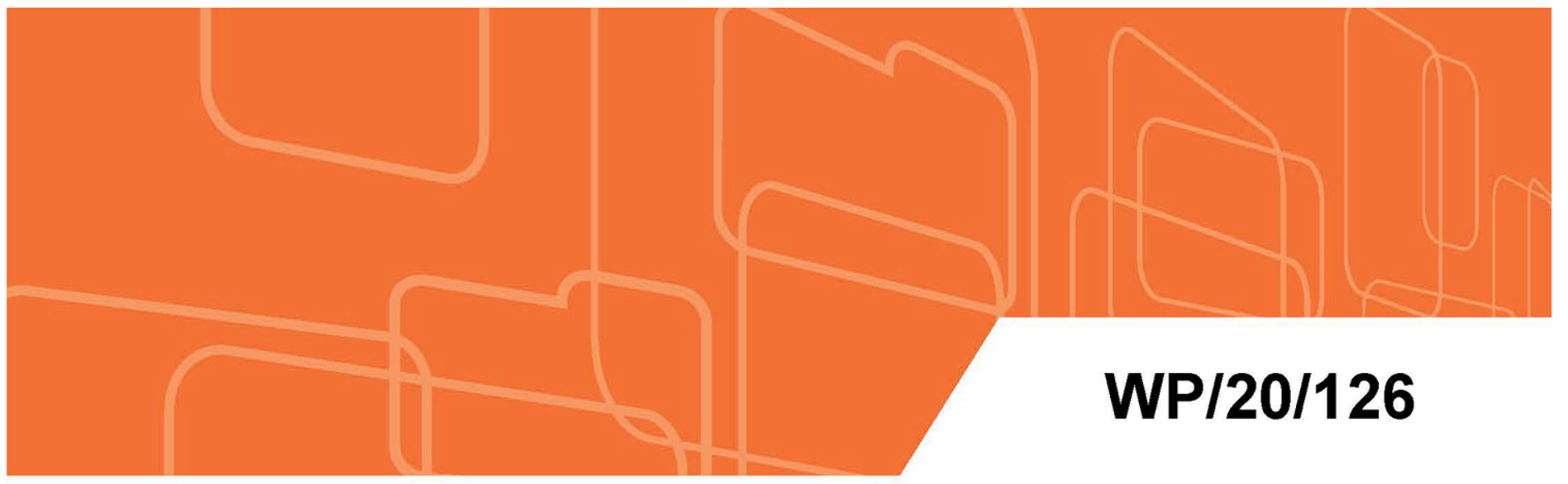

IMF Working Paper

\title{
Patterns in Invoicing Currency in Global Trade
}

by Emine Boz, Camila Casas, Georgios Georgiadis, Gita Gopinath, Helena Le Mezo, Arnaud Mehl, Tra Nguyen

IMF Working Papers describe research in progress by the author(s) and are published to elicit comments and to encourage debate. The views expressed in IMF Working Papers are those of the author(s) and do not necessarily represent the views of the IMF, its Executive Board, or IMF management. 


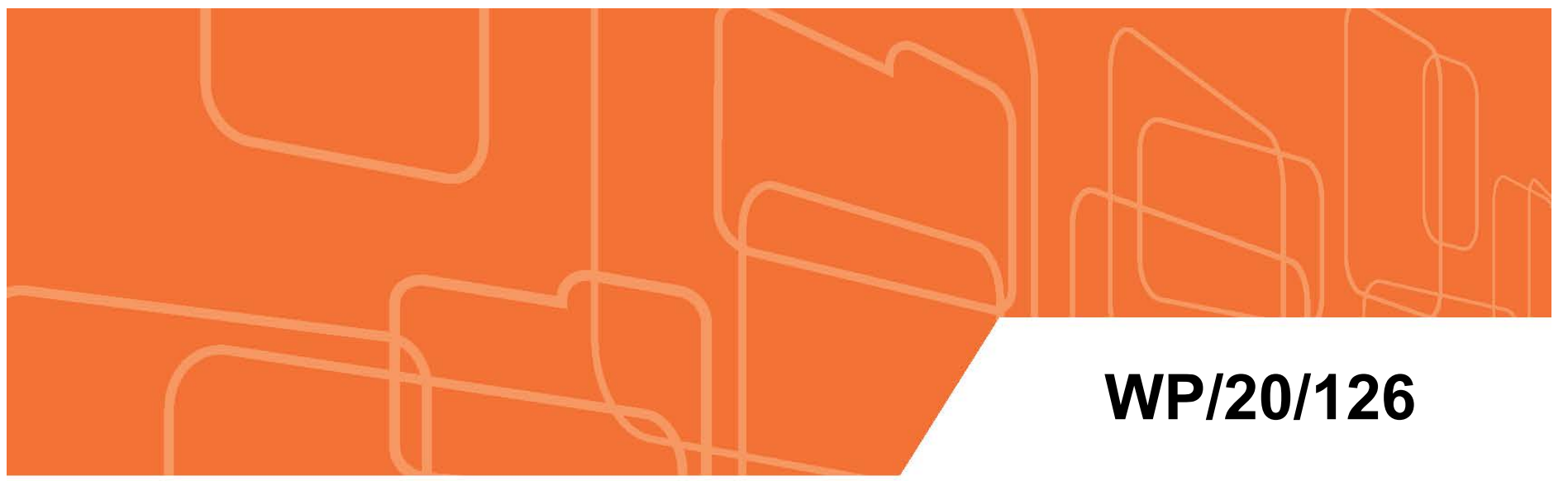

\section{IMF Working Paper}

\section{Patterns in Invoicing Currency in Global Trade}

by Emine Boz, Camila Casas, Georgios Georgiadis, Gita Gopinath, Helena Le Mezo, Arnaud Mehl, Tra Nguyen

IMF Working Papers describe research in progress by the author(s) and are published to elicit comments and to encourage debate. The views expressed in IMF Working Papers are those of the author(s) and do not necessarily represent the views of the IMF, its Executive Board, or IMF management.

I N T E R N A T I O N A L M O N E T A R Y F U N D 


\title{
IMF Working Paper
}

Research Department

\author{
Patterns in Invoicing Currency in Global Trade ${ }^{1}$ \\ Prepared by Emine Boz, Camila Casas, Georgios Georgiadis, Gita Gopinath, \\ Helena Le Mezo, Arnaud Mehl, Tra Nguyen \\ Authorized for distribution by Gita Gopinath
}

July 2020

IMF Working Papers describe research in progress by the author(s) and are published to elicit comments and to encourage debate. The views expressed in IMF Working Papers are those of the author(s) and do not necessarily represent the views of the IMF, its Executive Board, or IMF management.

\begin{abstract}
This paper presents the most comprehensive and up-to-date panel data set of invoicing currencies in global trade. It provides data on the shares of exports and imports invoiced in US dollars, euros, and other currencies for more than 100 countries since 1990. The evidence from these data confirms findings from earlier research regarding the globally dominant role of the US dollar in invoicing - despite the comparatively smaller role of the US in global trade - and the overall stability of invoicing currency patterns. The evidence also points to several novel facts. First, both the US dollar and the euro have been increasingly used for invoicing even as the share of global trade accounted for by the US and the euro area has declined. Second, the euro is used as a vehicle currency in parts of Africa, and some European countries have seen significant shifts toward euro invoicing. Third, as suggested by the dominant currency paradigm, countries invoicing more in US dollars (euros) tend to experience greater US dollar (euro) exchange rate pass-through to their import prices; also, their trade volumes are more sensitive to fluctuations in these exchange rates.
\end{abstract}

JEL Classification Numbers: F14, F31, F44

Keywords: invoicing currency of trade, dominant currency paradigm, exchange rate passthrough

Authors’Email: eboz@imf.org, mcasaslo@banrep.gov.co,georgios.georgiadis@ecb.int, ggopinath@imf.org, helena.lemezo@ecb.int, arnaud.mehl@ecb.int, tnguyen4@imf.org

\footnotetext{
${ }^{1}$ We would like to thank (without implicating): Benoit Coeuré, Philippe Martin, Martin Schmitz, and colleagues at the Directorate General Statistics of the ECB for their help and advice on EU data; colleagues at the AfDB, BIS, EBRD, and SEACEN for directing us to contacts at national authorities; colleagues at the WCO and WTO for helpful discussions; and seminar participants at the ECB. The views expressed in this paper are those of the authors and do not necessarily reflect those of the IMF, the ECB, the Eurosystem, the Banco de la República (or their Board of Directors) and should not be reported as such. The invoicing currency data set described and used in this paper is available at https://www.imf.org/ /media/Files/Publications/WP/2020/Datasets/wp20126.ashx.
} 


\section{Introduction}

Recent literature in international macroeconomics departs from the standard openeconomy framework under which export prices are set in the producer's currency, and it postulates a dominant currency paradigm whereby export prices are instead set in a so-called vehicle currency (Gopinath, 2015; Gopinath et al., 2020). A key observation underlying this paradigm is that most global trade transactions are invoiced in just a few currencies - most often the US dollar, sometimes the euro - regardless of the countries involved in the transaction. It is critical to establish whether more recent and comprehensive data support this observation, since the predictions of the dominant currency paradigm differ from those of the standard producer currency pricing along several dimensions: the impact of exchange rate movements, the conduct of monetary policy, and the international spillovers of monetary policy from countries that issue a dominant currency.

Against this background, we assemble the most comprehensive and up-to-date panel data set of trade invoicing currency patterns for major currencies. The data set provides the respective annual shares of exports and imports invoiced in US dollars, euros, home currencies, and other currencies for 102 countries over the period from 1990 to 2019. ${ }^{1}$ Overall, the countries in our data set account for about $75 \%$ of global trade. Although coverage is sparse for the 1990s, it is quite comprehensive in more recent periods; overall, we have nearly 1,200 country-year observations each for imports and exports. We obtain the data from official sources through the websites of and data requests sent to central banks, statistics offices and customs/revenue authorities.

Our data set covers a diverse sample of countries. It includes 40 countries from Europe, 20 from Asia, 22 from Africa, 11 from Latin America, 4 from Oceania, 3 from the Middle East, and 2 from North America. The country coverage is also diverse in terms of income levels: 35 countries are advanced economies, and the remaining 67 are emerging market and developing economies. The substantial improvement in crosscountry coverage of trade invoicing data, which is this paper's main contribution, is essential to fostering further research in international macroeconomics. For instance, Ito and Chinn (2014) note that, "in contrast to the relatively rich theoretical literature on the choice of currency for trade invoicing, the empirical literature is thin. The paucity of empirical literature is due to data availability" (p. 8).

Our data set's broad time-series coverage allows us to document several stylised facts about the evolution of global and regional trade invoicing. The data confirm pre-

\footnotetext{
${ }^{1}$ The data used in this paper are those available by June 2020. The publicly available database will be updated periodically and may contain additional information.
} 
vious findings (see e.g. Gopinath, 2015) on the US dollar's dominance and on the overall stability of invoicing currency patterns in global trade; however, they also reveal a number of novel stylised facts. First, the data indicate that dollar and euro invoicing have both increased over time - despite the decline in the share of global trade accounted for by the US and the euro area (EA). Moreover, the data indicate notable changes in invoicing currency patterns for several countries in specific circumstances. In particular, we find that countries that joined the EA or the European Union (EU), EU candidate countries, and other European countries have experienced marked increases in the use of the euro as an invoicing currency - increases that typically occurred at the expense of the dollar. These findings are consistent with the theoretical literature's emphasis (see Gopinath and Stein, 2018; Mukhin, 2018) on the role of history, path dependence, and nonlinearities in the choice of a trade invoicing currency, including discrete events such as the establishment of currency unions and episodes of comprehensive institutional integration.

In order to illustrate the usefulness of the data set, we follow the existing literature and explore the role of vehicle currency invoicing for exchange rate pass-through to import prices and trade volumes. Combining our new data set on invoicing currency patterns with expanded and updated data sets for both trade price and volume indices, we find the pass-through to import prices and trade volumes from fluctuations in US dollar exchange rates to be higher than from fluctuations in the bilateral exchange rate between the importer's and the exporter's currencies. These findings confirm the results of Gopinath et al. (2020), who conduct similar analyses on a smaller sample.

Our paper is related to earlier efforts on assembling cross-country data sets of trade invoicing currency patterns. We contribute to this literature along several dimensions. Compared with Gopinath (2015), our data set includes twice as many countries and, perhaps more importantly, also a time dimension. Relative to other earlier data sets such as Kamps (2006), Goldberg and Tille (2008), and Ito and Chinn (2014) - ours covers 2-4 times as many countries and has more systematic coverage over time. ${ }^{2}$ It is noteworthy that, as compared with Gopinath (2015), Kamps (2006), Goldberg and Tille (2008), and Ito and Chinn (2014), our data set contains information on a much larger number of emerging market and developing economies, for which vehicle currency use is more relevant. Finally, we improve data quality for EU countries significantly

\footnotetext{
${ }^{2}$ The data set of Kamps (2006) includes 43 countries but only up until 2005; it was subsequently updated by Lafarguette (2015) to cover the period through 2015. The data set of Goldberg and Tille (2008) includes 24 countries up until 2003; that of Ito and Chinn (2014), 50 countries but only up until 2012; and that of Gopinath (2015), 51 countries through 2015. The data are typically available from the early or late 1990s. The exceptions are Goldberg and Tille (2008) and Ito and Chinn (2014), who have some (very limited) observations for the 1970s.
} 
over existing data sets by exploiting internal European Central Bank (ECB) information to ensure that definitions of invoicing currency data are harmonised with regard to trading partner composition. This contribution is important because European countries account for a large share of our and earlier country samples. ${ }^{3}$

The rest of this paper proceeds as follows. In Section 2, we present our global panel data set of trade invoicing currency patterns; we also explain our data collection process, discuss properties of the data, and document several stylised facts across countries and over time. Section 3 documents the results of exchange rate pass-through regressions. We conclude in Section 4 with a brief summary.

\section{A new data set of global trade invoicing currency patterns}

\subsection{Data collection process}

Information on the invoicing currency in trade is in general recorded and compiled by national customs/revenue authorities. Depending on country-specific circumstances, this information may then be routinely disseminated to national statistics offices and central banks. Given the resulting diversity across countries in the location and accessibility of invoicing currency data, we follow a three-pronged approach in the data collection process. ${ }^{4}$

First, for EU countries we rely on the annual data collection exercise on trade invoicing currency patterns carried out for the ECB's annual report on the International Role of the Euro (IRE; see e.g. European Central Bank, 2019); we also use data saved in non-publicly available ECB archives that are no longer reported by national authorities and that were never published in ECB reports. ${ }^{5}$ Second, for non-EU countries we search online for publicly available information on trade invoicing currency. Third, for nonEU countries that do not post such data online - which constitute the majority of countries - we contact national authorities and request trade invoicing currency data for their respective jurisdictions.

In particular, we contact governors' offices and senior officials in the statistics, pay-

\footnotetext{
${ }^{3}$ One challenge when working with European data is that countries often report invoicing shares only for trade with outside the EU or the EA. Proxying invoicing shares in trade vis-à-vis the rest of the world based on these requires additional assumptions.

${ }^{4}$ Note that we build our data set from scratch with the exception of only a few cases, in which we rely on data from Kamps (2006) and Lafarguette (2015).

${ }^{5}$ Not all data available to the ECB are always published as reports typically focus on particular themes and are subject to space constraints.
} 
ments and international departments of central banks in Europe, the Western Hemisphere, Asia, Africa, and the Middle East with a formal request for time-series data on their respective countries' trade invoicing currency shares. We first contact central banks because they are the IMF's and especially the ECB's most natural counterparts. If we do not receive a response or if the invoicing currency data is not available from central banks, we turn to ministries of finance, statistics offices, and customs/revenue authorities. In many cases, if invoicing currency data are not readily available then we ask national authorities to compile them for us - provided the data needed for compilation are available.

Notwithstanding the extensive inter-institutional relationships between the IMF/ECB and national authorities, a challenging component of this data collection exercise is identifying the relevant contact points. For that purpose, we leverage a broad range of formal and informal contacts maintained at the ECB, the IMF, the European Bank for Reconstruction and Development, the African Development Bank, the African Association of Central Banks, the Asian Development Bank, the Bank for International Settlements, and the South East Asian Central Banks Centre. Overall, we contact national authorities of some 120 countries between July 2019 and June 2020 with requests for sharing information on their trade's currency of invoicing. The data for more than half of the countries in our data set are obtained through such requests.

\subsection{General data properties and definitions}

It would be ideal if the data we receive were consistent in all relevant dimensions: definitions of the data over time; the coverage of currencies, goods, and trading partners; whether the data represent invoicing or rather payment/settlement currency; the scope of data coverage (i.e., whether they capture the universe of all trade transactions or merely a survey-generated subset); the methods of aggregating individual transactionlevel data; and the treatment of re-exports. There is, unfortunately, no common international standard - comparable, for instance, to the IMF Balance of Payments Manual conventions - to ensure a harmonised reporting of trade invoicing currency data in all of these respects. ${ }^{6}$ One must bear in mind that the lack of harmonised data across countries and over time has also afflicted earlier efforts that assembled cross-country data sets of trade invoicing currency patterns.

As a result, our data sometimes differ across countries and even within a country over time. For example: following previous research, we use information on payment/

\footnotetext{
${ }^{6}$ In fact, for the update of the $6^{t h}$ edition of the Balance of Payments Manual international trade classified by currency has been included as one of the research topics.
} 
settlement currency for countries for which information on invoicing currency patterns is not available. ${ }^{7,8}$ To the extent that we have the relevant information, we document these country-specific features of the data in Table A.1 in Appendix A.

\subsection{Potential alternative data sources}

It is worth discussing potential alternative sources for invoicing currency information, such as trade finance data or the Society for Worldwide Interbank Financial Telecommunication (SWIFT; used by Bahaj and Reis, 2020, among others). First, SWIFT is a network that enables financial institutions to send and receive messages on financial transactions to and from one another in a secure and harmonised manner. Yet SWIFT neither clears or settles payments nor is it directly involved in the transfer of funds. Instead, SWIFT messages amount to payment orders settled via correspondent accounts that banks hold with each other. The most limiting aspect of SWIFT data for the purpose of constructing a trade invoicing currency data set is the difficulty of distinguishing between payment orders that concern trade and those that concern other transactions. ${ }^{9}$ Further work is needed to assess how much of the universe of trade transactions is captured by SWIFT data.

Trade finance data can be an alternative source of information on invoicing currency patterns. Yet one problem that arises is that the availability of trade finance data is fragmentary (Committee on the Global Financial System, 2014). A second problem is that the use of trade finance is heterogeneous across countries in a way that could bias the sample. For example, Schmidt-Eisenlohr (2013) shows that the optimal design of trade finance depends on the exporter and importer countries' relative costs of contract enforcement and financing. So for similar financing costs, exports to a country with weak enforcement should be paid using cash in advance; whereas countries with stronger enforcement should be supplied through open accounts. When firms in countries with weak contract enforcement trade with each other, bank finance (as supplied by letters of credit) is preferable, because it resolves commitment problems

\footnotetext{
${ }^{7}$ Information on the currency composition of trade payments/settlements is typically recorded by central banks based on input from banks in the context of compiling balance-of-payments statistics.

${ }^{8}$ Figure B.1 in Appendix B presents a comparison for the three countries in our data set for which we have information on both invoicing and payments/settlement currency.

${ }^{9}$ For example: although Bahaj and Reis (2020) are interested in trade invoicing currency, they focus on message types MT 103 and MT 202 - which cover single-customer and bank-to-bank payment message types. The baseline employed by Bahaj and Reis does not incorporate message type MT 400, which is a message from a bank, acting on behalf of an importer, confirming to a bank acting on behalf of an exporter that payment has been made by the importer (the actual payments backing MT 400 are recorded separately in SWIFT as message types MT 202 or MT 103). Indeed, the reason Bahaj and Reis do not use MT 400 messages in their baseline is that not every payment for international trade involves an MT 400 message.
} 
on both sides. Against this background, one concern with trade finance data and their availability is selection bias at the country level. In addition, it is not clear whether the currency in which trade finance is denominated coincides with the trade invoicing currency.

\subsection{EU-specific considerations}

Assembling consistent data for EU countries poses specific challenges, and our efforts to overcoming these challenges is an important improvement relative to the work of Goldberg and Tille (2008), Ito and Chinn (2014), and Gopinath (2015). In particular, data for EU countries are usually available for three different trading partner compositions: invoicing currency shares in countries' trade with the rest of the world, with non-EU countries, and with non-EA countries. ${ }^{10}$ For cross-country comparability, we are interested in data for the first of these - that is, invoicing currency shares in countries' trade with the rest of the world. Unfortunately, data for this particular trading partner composition is available for only a few EU countries (i.e., at least for the entire period of interest). So in order to maximise time-series coverage of the data on invoicing currency shares in EU countries' trade with the rest of the world, previous data sets often included combinations of (adjusted versions of) the time series for these three trading partner compositions.

An example of the issues at stake is the case of Spain. The left panel of Figure 1 plots the US dollar's share of export invoicing for various trading partner compositions. The time series for our variable of interest - the share of Spain's exports to the rest of the world invoiced in US dollars - is available only for the period 2009-2013. In contrast, information on the dollar's share is available for Spain's exports to non-EA countries from 1999 to 2013 and (via Eurostat) for Spain's exports to non-EU countries from 2010 to 2018. In constructing a time series for the share of Spain's exports to the rest of the world invoiced in dollars, the standard approach has been (i) to assume that all intra-EU/EA trade is invoiced in euros and then (ii) to construct an adjusted time series as a proxy for invoicing shares with respect to the rest of the world.

The adequacy of assuming that all intra-EU/EA trade is invoiced in euros can be verified when there is data on invoicing in trade with the rest of the world. For instance, while the share of Spain's exports to the rest of the world invoiced in US dollars actually averaged $21 \%$ over 2009-2013, that share amounted to only $14 \%$ (16.6\%) when assuming all intra-regional trade is invoiced in euros and using data on exports

\footnotetext{
${ }^{10}$ The trade invoicing currency data for EU countries that can be found on Eurostat's website pertain to trade with non-EU countries.
} 
Figure 1: US dollar invoicing shares for Spain and Hungary
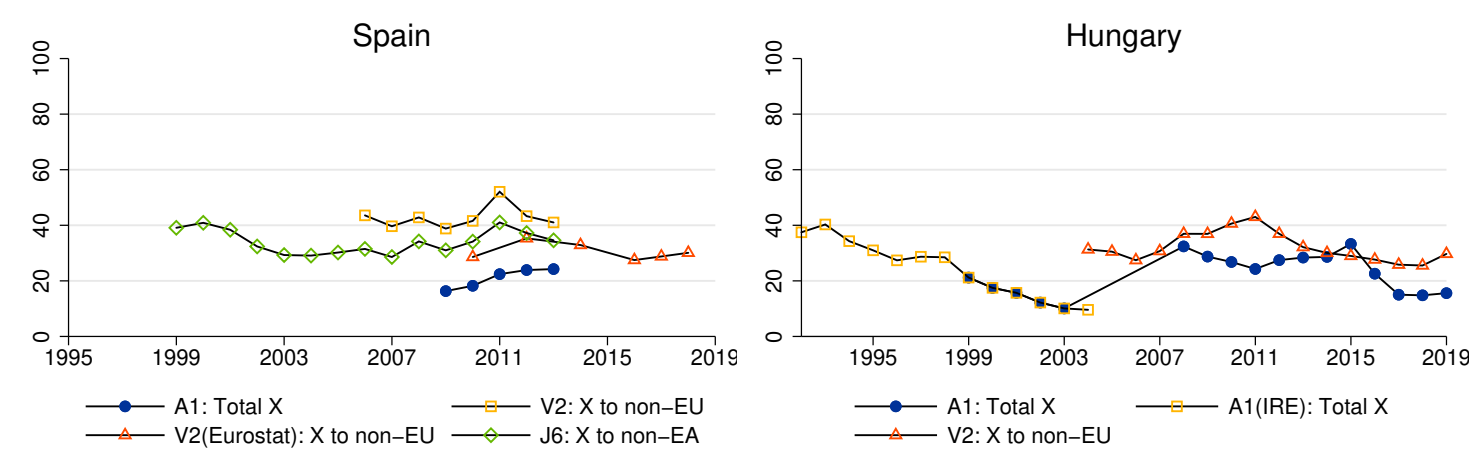

Note: The figure plots raw data on US dollar shares in export invoicing for Spain (left panel) and Hungary (right panel). In each panel, the invoicing shares are shown for different trading partner compositions: for total exports to the entire rest of the world (A1), exports to non-EU countries (V2), and exports to non-EA countries (J6). The figure also distinguishes among different data sources - namely, the 2020 ECB IRE (A1, V2, J6) in addition to historical, non-publicly available (and unreported) internal ECB records from past editions of the ECB's International Role of the Euro report.

to non-EU (EA) countries. These discrepancies are quantitatively significant, and they imply substantial spurious level shifts in invoicing currency shares in previous data sets for periods in which the data source switched among the various trading partner compositions.

We adopt a different approach for countries that have limited data on invoicing shares in trade with the rest of the world but have comprehensive data on invoicing shares in trade with non-EU and non-EA countries. In particular, we use changes in the latter to extend the former. In Spain's case, for example, we first compute percentage-point changes in the share of exports to non-EA countries invoiced in US dollars for 1999-2008 and, similarly, the shares to non-EU countries for 2014-2018. We then extend our time series for the rest of the world, which covers only the 20092013 period, in two directions: backward to 1999 by applying changes in the non-EA series; and forward to 2018 by applying changes in the non-EU series. In adopting this approach, we implicitly assume that yearly changes in invoicing currency shares are the same across EA and non-EA trading partners as well as across EU and non-EU trading partners. ${ }^{11}$ We believe this assumption is weaker than the assumption that all intra-regional trade is invoiced in euros, which (as previously mentioned) is in general not consistent with the data.

${ }^{11}$ This method cannot be applied when there are no overlapping years for invoicing shares in trade with the rest of the world and in trade with non-EU and non-EA countries. We handle these instances in a case-by-case manner and document each one in detail. In such cases, we generally do not assume - unlike in previous work - that all intra-regional trade is invoiced in euros. 
An additional challenge of special pertinence to EU countries is that, even for a given trading partner composition, the properties of the data may change over time. For instance, for some countries data for earlier periods are based on customs information and reflect the universe of trade whereas data for later periods is based on surveys. An example for this is Hungary, as shown in the right panel of Figure 1. In that graph, the yellow line with square markers represents the share of Hungarian exports to the rest of the world invoiced in US dollars, which was provided to the ECB by national authorities before the 2020 data collection exercise; the blue line with round markers represents the share of Hungarian exports to the rest of the world invoiced in dollars but as provided by national authorities during that collection exercise. Although the two series coincide prior to 2003, only the latter is available from 2008 onward. Our communication with Hungarian authorities reveals that, in the 2020 data collection exercise, post-2008 data are based on surveys and not on customs records. This is plausible, as Hungary joined the EU in May 2004 and, ever since, intra-EU trade has been exempt from customs; hence no invoicing currency information is recorded. It would seem sensible to rely on the currency invoicing data obtained from surveys after 2008, but Figure 1 also shows that, in 2015, the share of Hungarian exports to the rest of the world invoiced in dollars exceeds the corresponding share in the universe of Hungary's non-EU exports invoiced in dollars (represented by the line marked with red triangles). It is always possible for such peculiarities to arise in survey data. To address the issue in this case, we again apply the yearly changes in invoicing currency shares from the extra-EU trade series to extend forward the invoicing currency shares with respect to the rest-of-the-world series from the customs data provided to the ECB prior to its 2020 data collection exercise.

Another issue with EU countries' data is that the time coverage may differ across "vintages". For example, a new vintage can start at a later date than the previous one - that is, rather than starting on the same date for all vintages. In such cases, the new vintage has missing observations in earlier years relative to the old vintage. This outcome can arise because of changes in standards, technology, and/or the definition of variables. When such changes occur, national authorities often provide data only for the time period spanning their most recent data collection exercise. In order to maximise time-series coverage and the degree to which the data reflect consistent variable definitions and standards over time, we screen internal (non-publicly available) ECB archives and carefully combine data provided by national authorities in the most recent data collection exercise with the data they provided for earlier editions of the ECB's International Role of the Euro.

Finally, for some countries Eurostat reports data on its website for years when the 
ECB receives no input in its data collection exercise. The reason for this is that while EU countries' national statistics offices are legally obliged to report data to Eurostat, the ECB's data collection exercise involves national central banks (rather than statistics offices) and is based on voluntary best efforts. It may also be the case that data are available from both Eurostat and the ECB data collection exercise but that the two data sets differ. One reason for such differences is that reporting from national authorities is not synchronised and data are subject to revision. Another reason is that while Eurostat data represent information on invoicing in goods trade, ECB data represent information on payment/settlement currency in goods and services trade. An example of this issue is given by Spain (left panel in Figure 1). Communication with national authorities reveals that data for Spain's exports to non-EA countries from 1999 to 2013 reflects information on the settlement currency of goods and services trade. The underlying reporting system was abandoned in 2013, and hence settlement currency information has not been recorded anymore since then. In contrast, data for Spain's exports to non-EA countries provided by Eurostat for 2010 to 2018 reflects information on the invoicing currency for goods trade.

We exploit institutional contacts between the Statistics Department of the ECB and national central banks in EU countries to cross-check the data obtained by combining time series across vintages and trading partner compositions. Since data availability in general differs across EU countries, the steps we take in this process also differ. To save space, we do not discuss the details for each EU country and instead consider only two illustrative countries: Spain and Hungary. ${ }^{12}$ Because of our handling of the aforementioned issues associated with EU countries, we believe that our data set reflects invoicing currency patterns in trade with the rest of the world more accurately - and more comprehensively - than the data sets constructed by Goldberg and Tille (2008), Ito and Chinn (2014), and Gopinath (2015).

\subsection{Country and time-series coverage}

Our data set is an unbalanced panel on invoicing patterns in goods trade of 102 countries from 1990 to 2019. ${ }^{13,14}$ Figure 2 illustrates the country and time-series coverage

\footnotetext{
${ }^{12}$ Details on the data construction for other EU countries are available from the authors on request.

${ }^{13}$ As information on trade invoicing currency is recorded by customs/revenue authorities, which only record goods trade, our data in general does not reflect invoicing currency patterns in services trade. However, when we resort to payment/settlement data, services trade may be covered as well.

${ }^{14} \mathrm{Six}$ of the countries included in the country count of 102 are members of the Western African Monetary Union: Benin, Burkina Faso, Guinea-Bissau, Mali, Niger and Togo. For these countries, we only have the aggregate currency union-wide data, which include intra-currency union trade. For Senegal and Cote d'Ivoire we have country-specific data (also including trade with the rest of the currency union).
} 
Figure 2: Country coverage of US dollar export invoicing data
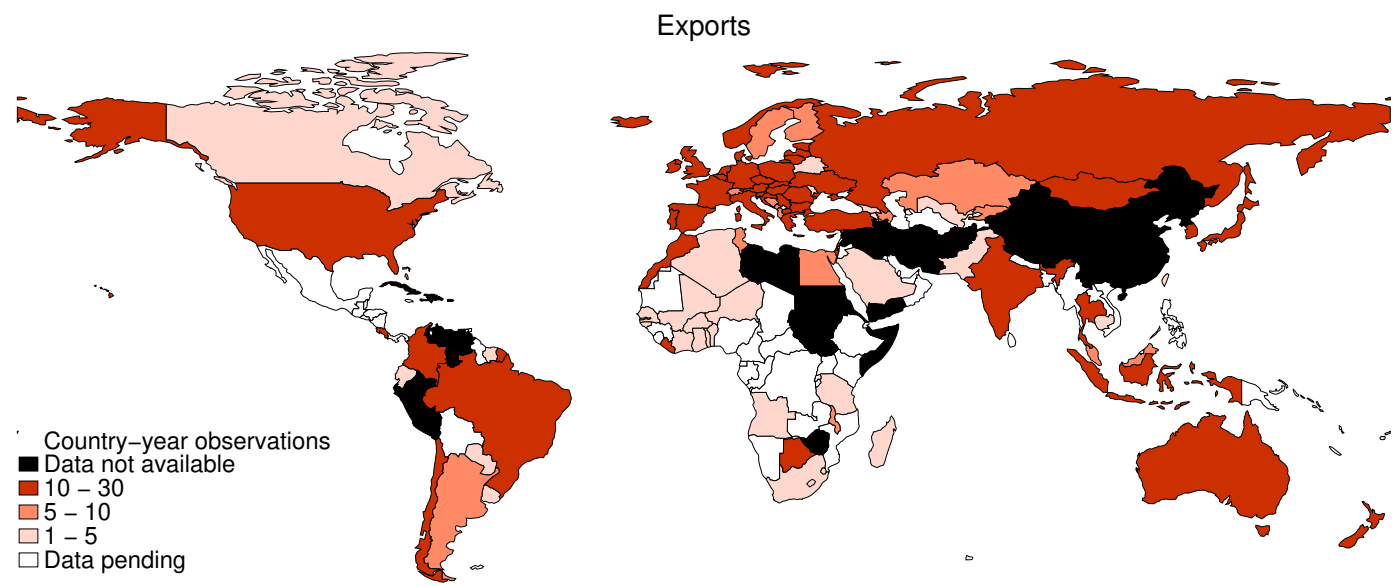

Note: The figure shows the global country coverage of our data on US dollar export invoicing shares. Different shades of red correspond to different numbers of available annual observations. For the countries marked in black, data are either unavailable (as confirmed by national authorities) or have not been requested. Countries marked in white are those for which data requests are pending.

for US dollar export invoicing shares in our data set; coverage of the shares of euro invoicing and imports is very similar. ${ }^{15}$ Our data set provides information on the share of trade invoiced primarily in dollars and in euros - but in many cases also on the share of trade invoiced in home currency. ${ }^{16}$

Unfortunately, for various reasons, our data set does not include several advanced and developing countries. In the case of China, authorities do not participate in our data collection exercise, but limited information on the share of the renminbi used as settlement currency in goods trade is available from previous data sets. Because Canada no longer stores the detailed invoicing currency information used in Devereux et al. (2017), our data is limited to one observation (obtained from Kamps (2006)) for the year 2001. ${ }^{17}$ In other cases, customs authorities do not collect invoicing currency data or do not collect it with sufficient accuracy. For instance, disclosure of the currency of invoicing is not mandatory in customs declaration forms in Mexico. Finally, our data set misses a number of other advanced and developing countries - such as Singapore,

\footnotetext{
${ }^{15}$ For information on the country data, see Table A.1. We received data for additional years and countries after the publication cutoff date of this working paper. In particular, additional years are available for Austria, Georgia, Guyana, Italy, Macao, Malawi, Ghana, Paraguay, and Senegal, and additional countries are Democratic Republic of Congo, Mozambique, the Philippines, and Uganda. We will incorporate this additional country data in future updates of the data set.

${ }^{16}$ Information on the share of trade invoiced in other currencies is fairly scattered, so it is excluded from our data set. However, these data are available upon request.

${ }^{17}$ However, we use the time averages over of the invoicing currency shares from Devereux et al. (2017) for the period 20002-2008 in our regressions in Section 3 to maximise time coverage.
} 
Figure 3: Evolution of country and world export share coverage
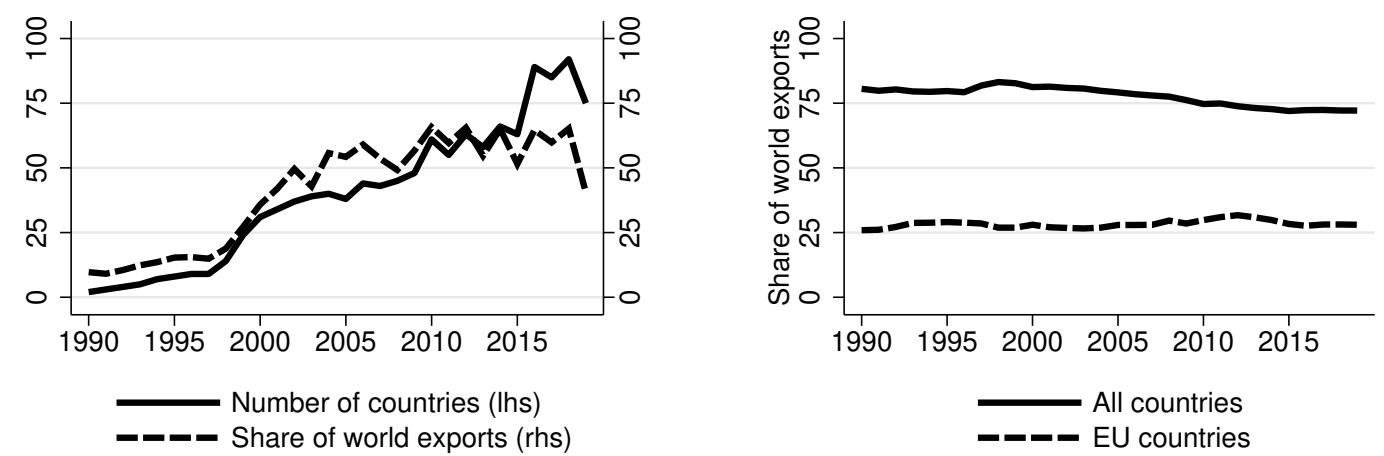

Note: The figure plots the coverage of the data on the invoicing currency shares of exports over time. The left panel shows the evolution of our country count and of the share of world exports covered in the raw data; the right panel shows the share of world exports that our data cover after interpolation and extrapolation.

Nigeria, and Vietnam. Although our data set is a clear improvement over previous assemblages, Central America and Sub-Saharan Africa still stand out as regions for which we have relatively limited information and country coverage. The latter is a serious deficiency because, for historical reasons, the euro could play a leading role as a vehicle currency in many African countries. Moreover, especially in recent years the renminbi may have started to play an increasingly important role as a vehicle currency in many African countries against the background of the region's fast growing trade with China.

The country coverage of our data set changes over time. The solid line in the left panel of Figure 3 reveals that the maximum country coverage for data on countries' exports invoiced in US dollars in any given year is 92 (in 2018). ${ }^{18}$ The dashed line shows that our data set covers more than half of world exports since the early 2000s and as much as about two thirds of world trade after 2010. Coverage for euro invoicing and for imports is, as before, very similar.

In the figure's left panel, most of the variation over time in the coverage of the share of world trade stems from changes in country coverage. Those changes make it difficult to explore trends in invoicing currency patterns at the level of regional or incomelevel country aggregates, since variation would largely reflect countries entering and dropping out from the sample rather than from changes in invoicing currency choices. So when constructing regional and income-level country aggregates, we interpolate

\footnotetext{
${ }^{18}$ The maximum number of countries for which data is available on dollar import invoicing shares in a given year is 93 ; it is 90 and 92, respectively, for euro export and import invoicing shares (all in 2018).
} 
and extrapolate missing data to obtain a balanced panel. For extrapolation, we use the earliest (latest) available data point to extend backward (forward); in each case, we hold constant the value of the first (last) available data point. Note that this simple extrapolation will understate any secular trends in invoicing currency share patterns exhibited by the regional or income-level country aggregates.

After this interpolation and extrapolation, our data cover around $75 \%$ of global exports; see the solid line in the right panel of Figure 3. The dashed line in that panel shows that EU countries account for roughly one third of the share of global exports covered by our data. Once again, the data for euro invoicing and imports are similar.

\subsection{Stylised facts}

\subsubsection{The US dollar's dominant role in global trade}

Much as in Gopinath's (2015) Figure 2, the left panel of Figure 4 compares the share of exports invoiced in US dollars and euros in global exports (left-hand bar) and the share of exports to the US and EA countries in total global exports (right-hand bar). The graph reveals that the share of global exports invoiced in dollars is much larger than the share of exports destined to the US. This difference indicates that the dollar plays an outsized role in the invoicing of global exports; the patterns for imports are quite similar. The right panel of Figure 4 establishes that the dollar's leading role reflects more than its use for the invoicing of commodity exports: once exports of commodities are removed from both the invoicing and export shares, the dollar share of invoicing $(23 \%)$ still exceeds - by a sizeable margin - the share of exports destined for the US $(10 \%)$.

Figure 4 also reveals that the euro's share in global export invoicing is an impressive $46 \%$. While this appears as a very large number, recall that a currency's vehicle currency role can be gauged only by comparing its share in global invoicing to the share of global exports that involve the jurisdiction issuing the currency. This comparison reveals that the euro's share in global export invoicing is not much larger than its share, $37 \%$, of exports destined to EA countries. ${ }^{19}$

Independently of this comparison, there are several reasons why we find such large export shares for euro-invoiced and EA-destined global trade. First, our data include both the values and invoicing currency shares of intra-EA exports. As one would expect, and as Figure 1 illustrates, a large share of intra-EA trade is invoiced in euros. ${ }^{20}$

\footnotetext{
${ }^{19}$ In data from the IMF's Direction of Trade Statistics that includes all countries whether or not information on invoicing currency is available, only $24 \%$ of global exports were destined for EA countries in 2019 .

${ }^{20}$ It could be argued that considering intra-EA trade artificially boosts the share of global exports
} 
Figure 4: Shares of global trade and invoicing currency
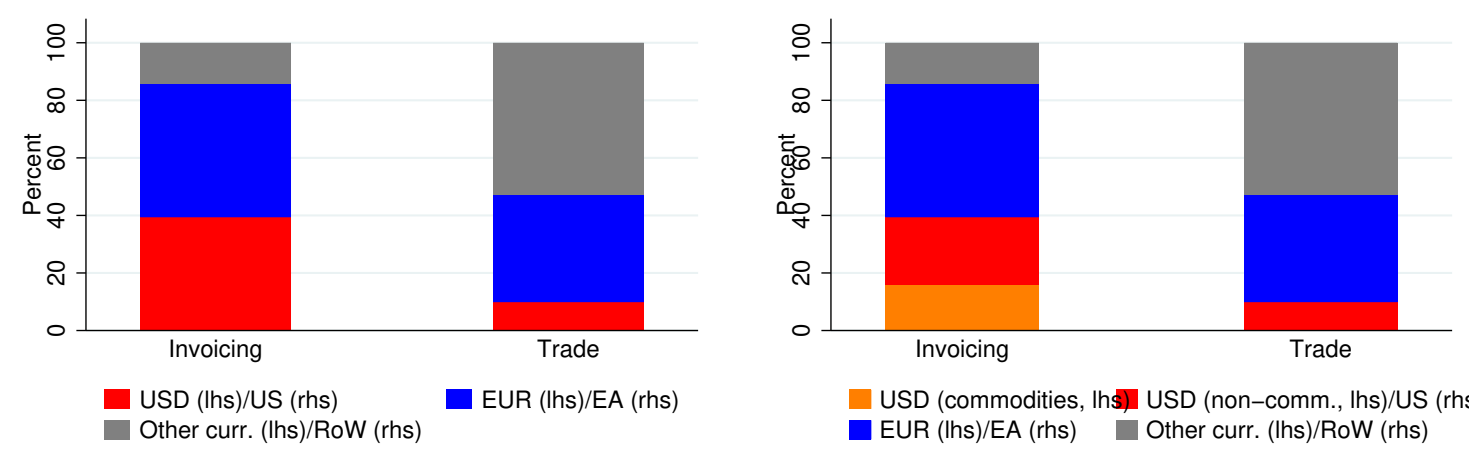

Note: The figure plots the share of exports to the US, the EA, and the rest of the world as well as the share of exports that are invoiced in US dollars, euros, and other currencies. Only countries for which we have invoicing data are considered; hence the trade shares shown exclude the exports of several large countries, including China and Mexico. Interpolated and extrapolated data are averaged over time from 1999 to 2019. The left panel replicates Figure 2 in Gopinath (2015), which is based on data for the period 1999-2014; the right panel presents the same information except that exports invoiced in dollars are split into commodity and non-commodity exports. To do so, we assume that all commodity exports are invoiced in dollars and we use data on the share of exports due to commodities; here commodity trade is measured as the sum of the shares - obtained from the World Bank's "World Development" Indicators - due to agricultural raw materials, ores and metals, and fuels.

Second, despite our efforts to expand the data set's coverage of developing countries, we still have better coverage for Europe - even beyond the EA - than for all other regions. And similarly to the case of EA countries, a large share of intra-EU/European trade is invoiced in euros.

The disproportionate role of the US dollar in global trade invoicing can be discerned also at the country level. The left panel of Figure 5 compares the share of countries' exports to the US in total exports with the share of their exports invoiced in dollars; in almost all cases, the latter is much greater than the former. From a global perspective, the euro's share in trade invoicing is well aligned with the share of trade in which at least one EA country is involved (see Figure 4); it is therefore interesting that, as shown in the right panel of Figure 5, the euro does predominate in certain regions. In particular, non-EA European countries and several African countries use the euro for invoicing more than just in their exports to the EA. So even though the US dollar is the globally dominant currency in trade invoicing, the euro may be regarded as a regionally dominant currency in Europe and some parts of Africa.

invoiced in euros. But we include such trade when calculating the shares of both invoicing and trade, and we see no reason why a comparison of the two would be biased. 
Figure 5: Trade and invoicing currency shares at the country level
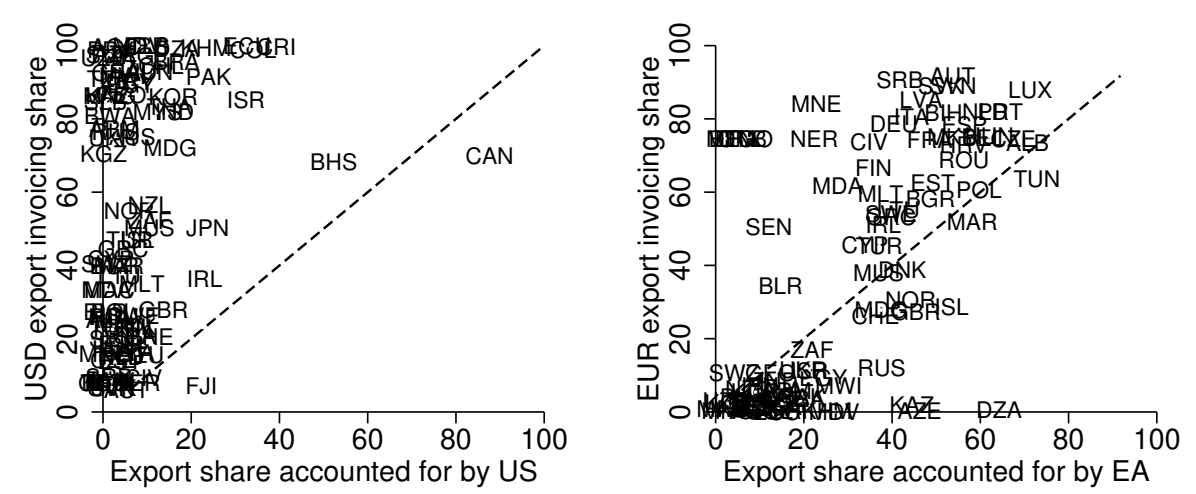

Note: The figure presents scatter plots of the share of countries' total exports accounted for by the US and the share of total exports invoiced in US dollars (left panel) as well as the share of total exports accounted for by the EA and the share of total exports invoiced in euros (right panel).

\subsubsection{Evolution of global invoicing currency patterns}

Figure 6 plots the evolution of the average export and invoicing currency shares that were plotted in the left panel of Figure 4. Figure 6 exposes the increasing concentration of invoicing in US dollars and euros over time. It is important to point out that this has been the case against the backdrop of declining shares of world exports to the US and the EA. The implication is that vehicle currency use has been on the rise.

We next unpack the global aggregates and look at changes in export-weighted averages for different country groups over time. It is apparent from Figure 7 that US dollar export invoicing shares vary little; the patterns for imports and unweighted averages (not shown here) are similar. For the most part, this stability holds at the regional and country-group level as well, with slight increases (decreases) over time for Asian (Latin American) emerging market economies. Euro invoicing shares are also stable overall, with the exception of a sharp increase for non-EA EU countries. Recall that our analysis of regional and income-level aggregates required the interpolation and extrapolation of missing data to prevent time-series variation attributable only to changes in country coverage. As already mentioned, our extrapolation approach is likely to understate secular trends in the evolution of invoicing currency patterns.

Moving on to the dynamics of trade invoicing at the country level, Figure 8 presents the average US dollar and euro invoicing shares for the time period prior to 2005 and after 2016. The figure's left panel shows that the share of trade invoiced in dollars has remained relatively stable at the country level. That said, a telling observation is that 
Figure 6: Global trade and invoicing currency shares over time
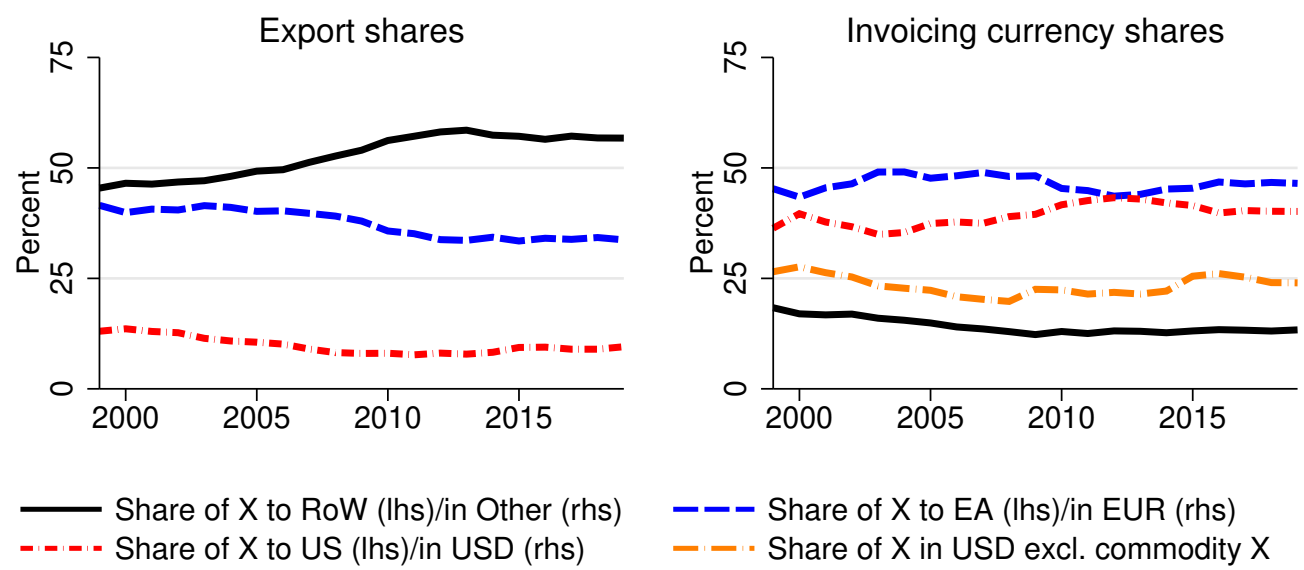

Note: The left panel depicts the evolution of the share of exports to the US, the EA, and the rest of the world in total global exports; the right panel plots the share of global exports that are invoiced in US dollars, euros, and other currencies. Only exports to countries for which we have invoicing data are considered. The graphs are based on interpolated and extrapolated data.

Figure 7: Evolution of invoicing currency shares for regional and income-level aggregates
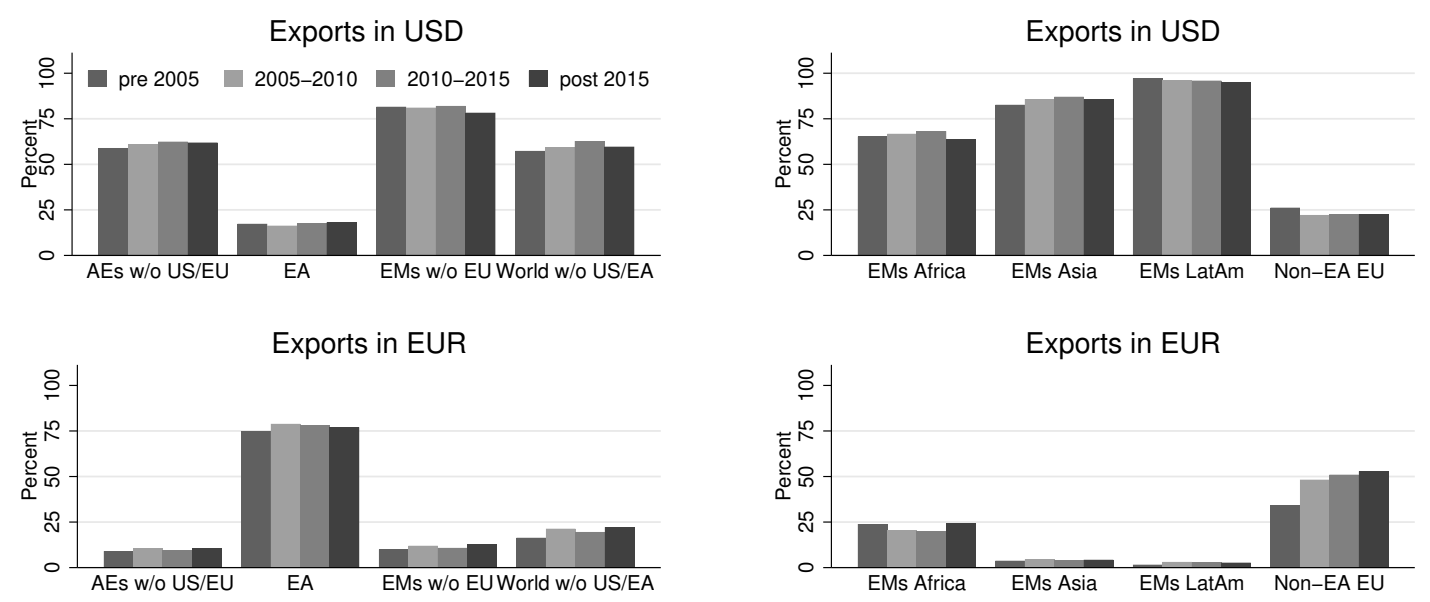

Note: The figure is based on interpolated and extrapolated raw data in order to avoid variation that stems exclusively from economies entering and exiting the sample. For each country, the data are weighted by its share of global exports. 
Figure 8: Evolution of invoicing currency shares at the country level
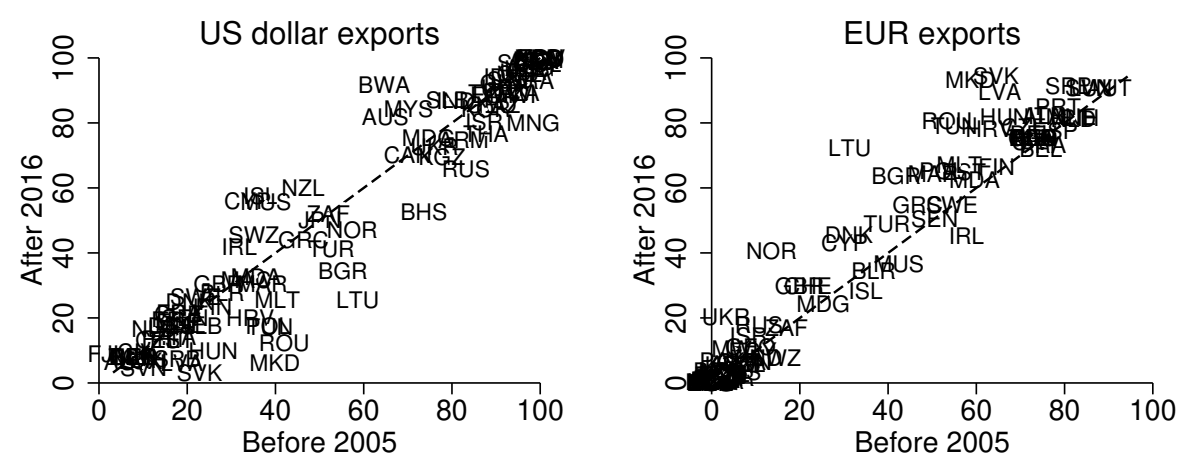

Note: The figure presents scatter plots of the shares of countries' exports invoiced in US dollars (left panel) and euros (right panel) both early and late in the sample period.

the number of countries whose share of exports invoiced in dollars has decreased (58) is greater than the number of countries for which that share has increased (36). In light of our previous evidence on global and regional aggregates, it is possible that the countries that experienced a decline in their dollar invoicing shares also have smaller trade shares. In contrast, the right panel of Figure 8 shows that the share of exports invoiced in euros has increased for more countries than it has declined (65 vs. 26) - a generalisation that is most applicable to European and several African countries.

Despite the overall stability in invoicing patterns over time, there are cases in which substantial shifts occur in relatively short time periods. Figure 9 illustrates this point by showing the full time-series data for selected European countries. ${ }^{21}$ The increase in these countries' export shares invoiced in euros is striking, especially when one considers that the shares of exports destined to the EA have either been fairly stable or exhibited only modest increases. Observe that, in these cases, the rise in the share of exports invoiced in euros is typically paralleled by a decline in the share invoiced in US dollars.

Our finding of a pronounced rise in euro's prominence throughout the EA's immediate neighbourhood is consistent with the analysis of Portes and Rey (1998), who describe the possibility of multiple equilibria in the international monetary system. In such an environment, major historical events - such as the creation of a monetary union - may induce a one-off increase in "thickness externalities" associated with transaction costs as well as a reduction in menu costs, changes that shift the international monetary system into an equilibrium characterised by greater use of the euro: in EA countries

${ }^{21}$ The euro shares prior to 1999 are calculated as the sum of the underlying currencies. 
Figure 9: Evolution of invoicing and export shares for selected European countries
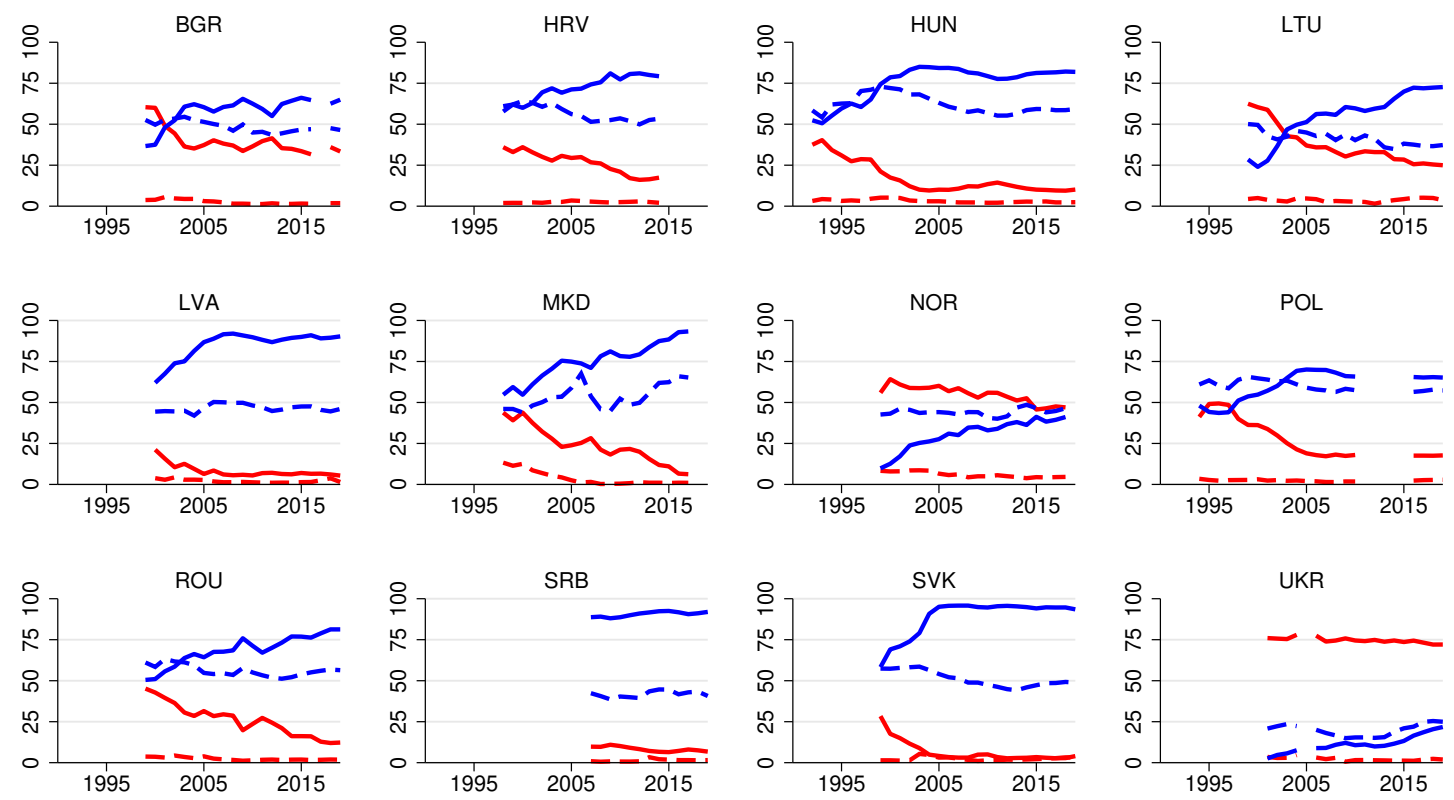

X in USD = - Share of $X$ to US

$X$ in EUR $\quad$ - - Share of $X$ to EA

Note: The figure plots the evolution of US dollar (solid blue lines) and euro export (solid red lines) invoicing shares as well as US (dashed red lines) and EA (dashed blue lines) export shares. 
and as a vehicle currency in trade between non-EA countries. ${ }^{22}$ Similarly, Bacchetta and van Wincoop (2005) show how strategic complementarities in price setting imply that the exporting country's market share becomes a crucial factor in the invoicing currency choice. ${ }^{23}$ The analysis of Bacchetta and van Wincoop (2005) suggests that introduction of the euro led to more use of the euro as an invoicing currency than the sum of the use of all the currencies it replaced.

In general, the evidence from our data set points to considerable inertia in global trade invoicing currency patterns. Yet the data also indicate that invoicing currency choices can change both radically and rapidly. Thus our empirical evidence is consistent with predictions in the theoretical literature on invoicing currency choice - research that emphasises the role of nonlinearities, path dependence, and history (e.g., the establishment of a currency union or episodes of deep institutional integration (see Gopinath and Stein, 2018; Mukhin, 2018).

\section{Exchange rate pass-through}

The choice of invoicing currency has important consequences for how relative prices are affected by exchange rate fluctuations when prices are sticky in said currency. The higher is the fraction of a country's imports that are invoiced in foreign currencies, the more sensitive is that country's inflation to changes in its currency's value relative to foreign currencies. Furthermore, the effects of external shocks on a country's trade flows and also on its trade balance adjustment can differ depending on the currency in which exports and imports are invoiced.

To shed light on these issues, this section reports the results of several exercises that relate fluctuations in trade prices and volumes to fluctuations in exchange rates and to (the available measures of) invoicing shares. We adopt the empirical strategy of Gopinath et al. (2020), but we use our extended and refined data set for invoicing currency shares. We also use the bilateral trade price and volume indices from Gopinath et al. (2020) but extend the data set to include the years 2016-2018. This extension generates more than 10,000 additional dyad-year observations, which is equivalent to nearly a $25 \%$ increase in the sample size. ${ }^{24}$ Exchange rates and additional controls are

\footnotetext{
${ }^{22}$ See also Rey (2001) as well as Devereux and Shi (2013).

${ }^{23}$ Gopinath et al. (2010) also study the role of strategic complementarities in price setting for invoicing currency choice.

${ }^{24}$ Whereas our invoicing data set covers more than 100 countries, consistent data on price and trade volumes at the dyad-product level are more restricted. The trade data set used for the estimations presented in this section includes 56 countries, and we have dollar and euro invoicing shares for 48 of them. As mentioned in Section 2, invoicing data for Canada are the average shares from 2002 to 2008 from Devereux et al. (2017). For Colombia, we use the observed export shares to proxy for import
} 
from the IMF's International Financial Statistics, the World Bank's World Development Indicators, and the St. Louis Fed's FRED database.

Our invoicing currency data capture the annual share of imports invoiced in US dollars, euros, and local currencies. However, for the estimations in this section we construct time-invariant shares by taking simple averages across years for which data are available. ${ }^{25}$ This choice of procedure is motivated by three factors. First, as mentioned in Section 2, for several countries there are gaps in the data. Using averages allows us to include all the available trade information without omitting the years for which invoicing shares are unknown. Second, at least part of the variation in annual invoicing shares is a mechanical result of fluctuations in exchange rates or changes in the composition of total trade, including commodities. ${ }^{26}$ Hence our use of averages eliminates the collinearity between our two regressors of interest. Third, as discussed in Section 2, invoicing shares are fairly stable over time; that characteristic makes time averages of trade shares a good proxy for year-specific measures.

\subsection{Empirical strategy}

We first estimate exchange rate pass-through regressions that link changes in countries' import prices to changes in their nominal exchange rates and other control variables of relevance to price setting. As proposed by Burstein and Gopinath (2014), we estimate an import price pass-through regression with a dynamic lag specification:

$$
\Delta p_{i j, t}=\alpha_{i j}+\delta_{t}+\sum_{k=0}^{K} \beta_{k} \Delta e_{i j, t-k}+\boldsymbol{\theta}^{\prime} \boldsymbol{Z}_{i, t}+\varepsilon_{i j, t}
$$

Here $\Delta p_{i j, t}$ represents the log change in the price index - expressed in the importer's currency - for imports from country $i$ by country $j$. The term $\Delta e_{i j, t}$ represents the log change in the bilateral nominal exchange rate, expressed in local currency per units of foreign currency; here a positive (resp. negative) value corresponds to depreciation (resp. appreciation). $k>0$ allows for lags in the pass-through of exchange rates to prices; we follow the literature and set $K=2$, allowing for a two-year lag. The additional controls in $\boldsymbol{Z}$ include the producer price index of exporter $i$ (and its two lags) to control for production costs. All regressions include country-dyad fixed effects

shares because customs officials collect invoicing information only for exports.

${ }^{25}$ Although we eliminate the time-varying aspect of our data for the exercises to be presented here, our data set's time dimension may be crucial for other analyses.

${ }^{26}$ Suppose that, for example, the dollar appreciates against the home currency; then the dollar share in the country's total export bill, which is expressed in home currency, increases - even if trade quantities and the associated invoicing currencies are unchanged. 
and time fixed effects to control for dyad-specific and global factors. With these fixed effects, pass-through is identified by the changes in exchange rates over time for a given dyad after stripping out global factors; hence the pass-through coefficients are comparable to those in earlier studies that run country-by-country regressions.

To assess the US dollar's role as a dominant currency in invoicing, we modify the specification laid out in Equation (1). We include the log change of the importer's exchange rate with respect to the dollar as well as the importer's bilateral rate with respect to trading partner $i$ :

$$
\Delta p_{i j, t}=\alpha_{i j}+\delta_{t}+\sum_{k=0}^{K} \beta_{k} \Delta e_{i j, t-k}+\sum_{k=0}^{K} \beta_{k}^{\$} \Delta e_{\$ j, t-k}+\boldsymbol{\theta}^{\prime} \boldsymbol{Z}_{i, t}+\varepsilon_{i j, t}
$$

where $e_{\$ j}$ denotes the log price of the dollar in the currency of $j$.

Next we interact the bilateral and the US dollar exchange rates with the share of imports invoiced in dollars, $S_{j}^{\$}:{ }^{27}$

$$
\begin{aligned}
\Delta p_{i j, t}= & \alpha_{i j}+\delta_{t}+\sum_{k=0}^{K} \beta_{k} \Delta e_{i j, t-k}+\sum_{k=0}^{K} \gamma_{k} \Delta e_{i j, t-k} \times S_{j}^{\$} \\
& +\sum_{k=0}^{K} \beta_{k}^{\$} \Delta e_{\$ j, t-k}+\sum_{k=0}^{K} \gamma_{k}^{\$} \Delta e_{\$ j, t-k} \times S_{j}^{\$}+\boldsymbol{\theta}^{\prime} \boldsymbol{Z}_{i, t}+\varepsilon_{i j, t} .
\end{aligned}
$$

For all specifications, we estimate both unweighted and trade-weighted regressions. Weights are computed as the average share of global non-commodities trade attributable to exports from $i$ to $j$.

\subsection{Results}

The estimation results are reported in Table 1. Columns (1) and (4) present the estimates for Equation (1). Using this standard specification, our results indicate that a $1 \%$ depreciation in country $j$ 's nominal bilateral exchange rate with respect to country $i$ is associated with an $0.7 \%$ increase in country $j$ 's import prices within the same year. ${ }^{28}$ These results suggest substantial pass-through of changes in the bilateral exchange rate - between the importer's and the exporter's currency - to import prices.

As reported in columns (2) and (5), which are based on Equation (2), the bilateral exchange rate's explanatory power is much reduced when the US dollar exchange rate

\footnotetext{
${ }^{27}$ Since we are using only import invoicing shares, we omit the corresponding superscript to simplify the notation.

${ }^{28}$ The coefficients for the lagged exchange rate included in the regression (not reported here) are statistically significant but economically small.
} 
Table 1: Exchange Rate Pass-Through into Import Prices

\begin{tabular}{lcccccc}
\hline & $(1)$ & $(2)$ & $(3)$ & $(4)$ & $(5)$ & $(6)$ \\
& $\Delta p_{i j, t}$ & $\Delta p_{i j, t}$ & $\Delta p_{i j, t}$ & $\Delta p_{i j, t}$ & $\Delta p_{i j, t}$ & $\Delta p_{i j, t}$ \\
\hline$\Delta e_{i j, t}$ & $0.733^{* * *}$ & $0.177^{* * *}$ & $0.245^{* * *}$ & $0.734^{* * *}$ & $0.318^{* * *}$ & $0.441^{* * *}$ \\
& $(0.00)$ & $(0.00)$ & $(0.00)$ & $(0.00)$ & $(0.00)$ & $(0.00)$ \\
$\Delta e_{i j, t} \times S_{j}^{\$}$ & & & $-0.119^{* * *}$ & & & $-0.270^{* * *}$ \\
& & & $(0.00)$ & & & $(0.00)$ \\
$\Delta e_{\$ j, t}$ & & $0.765^{* * *}$ & $0.621^{* * *}$ & & $0.600^{* * *}$ & $0.237^{* * *}$ \\
& & $(0.00)$ & $(0.00)$ & & $(0.00)$ & $(0.00)$ \\
$\Delta e_{\$ j, t} \times S_{j}^{\$}$ & & & $0.253^{* * *}$ & & & $0.644^{* * *}$ \\
& & & $(0.00)$ & & & $(0.00)$ \\
\hline Observations & 54,806 & 54,806 & 47,788 & 54,806 & 54,806 & 47,788 \\
R-squared & 0.239 & 0.271 & 0.289 & 0.258 & 0.287 & 0.402 \\
Dyads & 2,791 & 2,791 & 2,405 & 2,791 & 2,791 & 2,405 \\
\hline
\end{tabular}

Notes: The first (last) three columns present unweighted (trade-weighted) regressions. All regressions include two $\triangle \mathrm{ER}$ and $\Delta \mathrm{PPI}$ lags, and time and dyad fixed effects. Standard errors clustered by dyad. p-values in parentheses. ${ }^{* * *} \mathrm{p}<0.01,{ }^{* *} \mathrm{p}<0.05,{ }^{*} \mathrm{p}<0.1$.

is included as an additional regressor. In the unweighted (resp. weighted) regressions, the effect of the bilateral exchange rate declines sharply to $0.2 \%$ (resp. $0.3 \%$ ) whereas the effect of a $1 \%$ depreciation in the importer's currency vis-à-vis the US dollar is associated with a price increase of $0.8 \%$ (resp. 0.6\%). The estimated values for the pass-through of the dollar exchange rate to import prices are high, especially since time fixed effects strip out the effects that arise when all currencies appreciate or depreciate with respect to the dollar.

We next try to gauge whether the propensity to invoice imports in US dollars drives the importance of the dollar exchange rate. Columns (3) and (6) in Table 1 report estimates for Equation (3) when the bilateral and dollar exchange rate terms are interacted with the importer's share of imports invoiced in dollars. As anticipated, the dollar invoicing share plays a big role in the pass-through of exchange rate fluctuations to prices: a higher dollar invoicing share significantly increases the dollar pass-through. Our estimates indicate that a 1-p.p. increase in the dollar invoicing share leads to an 0.3-0.6-p.p. increase in the dollar pass-through, where the value depends on whether we use results from the weighted or rather from the unweighted regressions. At the same time, a higher share of imports invoiced in dollars reduces the bilateral exchange rate pass-through. Note also that including interactions that involve the dollar invoicing share improves the fit of our trade-weighted regressions, as shown in the lower part of 
Table $1 .{ }^{29,30}$

The results presented in Table 1 highlight the US dollar's dominance in international trade invoicing, but they do not preclude the existence of other vehicle currencies. To explore the role of such other currencies, we next compare the roles of the dollar and euro exchange rates. For this purpose, we estimate the following specification:

$$
\begin{aligned}
\Delta p_{i j, t}= & \alpha_{i j}+\sum_{k=0}^{K} \beta_{k} \Delta e_{i j, t-k}+\sum_{k=0}^{K} \gamma_{k} \Delta e_{i j, t-k} \times\left(S_{j}^{\$}+S_{j}^{€}\right) \\
& +\sum_{k=0}^{K} \beta_{k}^{\$} \Delta e_{\$ j, t-k}+\sum_{k=0}^{K} \gamma_{k}^{\$} \Delta e_{\$ j, t-k} \times S_{j}^{\$} \\
& +\sum_{k=0}^{K} \beta_{k}^{€} \Delta e_{€ j, t-k}+\sum_{k=0}^{K} \gamma_{k}^{€} \Delta e_{€ j, t-k} \times S_{j}^{€}+\boldsymbol{\theta}^{\prime} \boldsymbol{Z}_{i j, t}+\varepsilon_{i j, t}
\end{aligned}
$$

where $e_{€ j, t-k}$ is the log exchange rate of units of currency $j$ per euro and $S_{j}^{€}$ is the share of country $j$ 's imports invoiced in euros. Note that we cannot separately identify $\beta^{\$}$ and $\beta^{€}$ if time fixed effects are included, so we omit them and instead control directly for global factors. ${ }^{31}$ Because the euro was introduced in 1999 and we use two lags, the sample period for this regression starts in 2002.

The results for regressions that include the euro exchange rate are presented in Table 2. Columns (1) and (4) omit the dollar exchange rate and the interaction terms, so they are comparable to columns (2) and (5) of Table 1. As in the case of the dollar, including the euro exchange rate reduces the coefficient of the bilateral exchange rate. However, the pass-through of the euro exchange rate to prices is much smaller than that of the dollar, and the reduction in the bilateral exchange rate coefficient is also smaller. In the weighted regressions, the bilateral exchange rate actually dominates the euro. Columns (2) and (5) incorporate the dollar exchange rate. These results show that the US dollar dominates both the bilateral and the euro exchange rates when all three are included in the regression. ${ }^{32}$ Moreover, our model's fit deteriorates markedly

\footnotetext{
${ }^{29}$ One must bear in mind that the invoicing shares in our data set are calculated using a country's total trade whereas the price indices are constructed using only non-commodities - goods for which prices tend to be sticky, in which case the currency of invoicing is relevant. If the currency composition of imports of differentiated goods is different than the one we observe for total trade, then we may be under-estimating the effect of currency composition on the pass-through of the dollar exchange rate.

${ }^{30}$ As a robustness check, we re-run these regressions after excluding US dollar economies and economies whose currencies are pegged to the dollar. The results, which are very similar, are presented in Table A.2.

${ }^{31}$ These controls include global real GDP growth, the annual change in the global GDP deflator, global export volume growth, growth in the (deflated) West Texas Intermediate oil price, and the log of the Chicago Board Options Exchange Volatility Index.

${ }^{32}$ In particular, if we limit our sample to non-dollar, non-euro, non-pegged economies then the
} 
Table 2: Dollar vs. Euro Exchange Rate Pass-Through into Prices

\begin{tabular}{lcccccc}
\hline & $(1)$ & $(2)$ & $(3)$ & $(4)$ & $(5)$ & $(6)$ \\
& $\Delta p_{i j, t}$ & $\Delta p_{i j, t}$ & $\Delta p_{i j, t}$ & $\Delta p_{i j, t}$ & $\Delta p_{i j, t}$ & $\Delta p_{i j, t}$ \\
\hline$\Delta e_{i j, t}$ & $0.287^{* * *}$ & $0.179^{* * *}$ & $0.453^{* * *}$ & $0.445^{* * *}$ & $0.316^{* * *}$ & $0.803^{* * *}$ \\
$\Delta e_{i j, t} \times\left(S_{j}^{\$}+S_{j}^{€}\right)$ & $(0.00)$ & $(0.00)$ & $(0.00)$ & $(0.00)$ & $(0.00)$ & $(0.00)$ \\
& & & $-0.302^{* *}$ & & & $-0.626^{* *}$ \\
$\Delta e_{\Phi_{j t}}$ & & & $(0.04)$ & & & $(0.01)$ \\
& & $0.523^{* * *}$ & $0.250^{* * *}$ & & $0.590^{* * *}$ & $0.235^{* * *}$ \\
$\Delta e_{\oiint_{j, t}} \times S_{j}^{\$}$ & & $(0.00)$ & $(0.00)$ & & $(0.00)$ & $(0.00)$ \\
& & & $0.452^{* * *}$ & & & $0.707^{* * *}$ \\
$\Delta e_{€ j, t}$ & & & $(0.00)$ & & & $(0.00)$ \\
& $0.488^{* * *}$ & $0.156^{* * *}$ & 0.045 & $0.162^{*}$ & -0.200 & $-0.212^{* *}$ \\
$\Delta e_{€ j, t} \times S_{j}^{€}$ & $(0.00)$ & $(0.00)$ & $(0.39)$ & $(0.07)$ & $(0.11)$ & $(0.03)$ \\
& & & $0.716^{* * *}$ & & & $0.656^{* * *}$ \\
& & & $(0.00)$ & & & $(0.00)$ \\
\hline Observations & 40,904 & 40,904 & 35,401 & 40,904 & 40,904 & 35,401 \\
R-squared & 0.081 & 0.088 & 0.107 & 0.072 & 0.083 & 0.127 \\
Dyads & 2,739 & 2,739 & 2,353 & 2,739 & 2,739 & 2,353 \\
\hline
\end{tabular}

Notes: The first (last) three columns present unweighted (trade-weighted) regressions. All regressions include two $\Delta \mathrm{ER}$ and $\Delta \mathrm{PPI}$ lags, dyad fixed effects and global controls. Standard errors clustered by dyad. p-values in parentheses. ${ }^{* * *} \mathrm{p}<0.01,{ }^{* *} \mathrm{p}<0.05,{ }^{*} \mathrm{p}<0.1$. 
when the regressions include euro exchange rates. Finally, columns (3) and (6) add the interaction terms. As expected, having larger shares of dollar and/or euro invoicing decreases the pass-through of the bilateral exchange rate and increases the pass-through of dollar and euro exchange rates.

It is critical to note that the dollar dominates both the euro exchange rate and the bilateral exchange rate even after we control for euro and home-currency invoicing shares. ${ }^{33}$ These results suggest that the importance of the US dollar for price setting extends beyond its dominant role in invoicing. One possibility is that, given the outsized and growing role that the dollar also plays in firm financing, there is some complementarity in the currency choice for trade and finance (see e.g. Gopinath and Stein, 2018; Adler et al., 2020). Regardless of the factors underlying the US dollar's dominance, the results presented in Table 2 indicate that this currency plays a special role in the international price system.

\subsection{Trade volumes}

In light of the US dollar's oversized role in the invoicing of global trade, we next study how trade volumes are affected by the dollar exchange rate. To estimate trade elasticities, we modify Equations (1) to (3) by replacing the dependent variables with $\Delta y_{i j, t}$, the log change in the volume of exports from country $i$ to country $j$. Also, we include the importer's GDP growth - and two lags - as additional regressors to control for changes in import demand and we omit price indices. ${ }^{34}$

Table 3 presents the results from our regressions of trade volumes on exchange rates. As in the case of our exchange rate pass-through regressions, examining how trade flows and bilateral exchange rates are related yields the expected result: a depreciation of country $j$ 's currency against country $i$ 's currency is associated with a decrease in country $j$ 's imports from country $i$. However, if we add the US dollar exchange rate to the trade volume regressions then the coefficient for the bilateral exchange rate drops substantially; in the weighted regressions, it becomes statistically insignificant.

coefficient for the dollar exchange rate becomes close to 1 (see Table A.3).

${ }^{33}$ To illustrate this point, assume that the dollar and the euro each account for $50 \%$ of invoicing such that neither currency predominates. The estimates in column (3) then imply that, in this case, the estimated pass-through of the dollar exchange rate is $0.25+0.45 \times 0.5=0.48$, while the pass-through of the euro exchange rate is 0.40 . Thus, our estimates suggest that the dollar exchange rate has a larger impact on prices that cannot be exclusively explained by its oversized role in trade invoicing.

${ }^{34}$ As discussed in Gopinath et al. (2020), these regressions do not capture structural demand parameters; the reasons are that (i) we do not control for all relative prices and (ii) the importer's GDP growth is an imperfect measure of demand shocks. Moreover, our results partly capture expenditure switching effects. Nevertheless, the estimates are informative about the relationship between exchange rates and trade flows. 
So to compare the relative importance of the dollar and the euro in determining trade volumes, we again add the euro exchange rate as an additional regressor. When all three exchange rates are included, we find that (i) the dollar exchange rate dominates the other two and (ii) in the unweighted regression, the euro has no significant effect on trade volumes. Finally, we include interaction terms between exchange rates and the share of invoicing in dollars and/or euros. Larger shares of dollar or euro invoicing are associated with larger (in absolute terms) pass-through of the dollar or euro exchange rates, respectively. These results are robust to excluding all dollar and euro countries as well as economies with pegged currencies from the sample (see Table A.4). 
Table 3: Trade Elasticity with respect to Exchange Rates

\begin{tabular}{|c|c|c|c|c|c|c|c|c|}
\hline & $\begin{array}{c}(1) \\
\Delta y_{i j, t}\end{array}$ & $\begin{array}{c}(2) \\
\Delta y_{i j, t}\end{array}$ & $\begin{array}{c}(3) \\
\Delta y_{i j, t}\end{array}$ & $\begin{array}{c}(4) \\
\Delta y_{i j, t}\end{array}$ & $\begin{array}{c}(5) \\
\Delta y_{i j, t}\end{array}$ & $\begin{array}{c}(6) \\
\Delta y_{i j, t}\end{array}$ & $\begin{array}{c}(7) \\
\Delta y_{i j, t}\end{array}$ & $\begin{array}{c}(8) \\
\Delta y_{i j, t}\end{array}$ \\
\hline$\Delta e_{i j, t}$ & $\begin{array}{c}-0.124^{* * *} \\
(0.00)\end{array}$ & $\begin{array}{c}-0.040^{* *} \\
(0.02)\end{array}$ & $\begin{array}{c}-0.016 \\
(0.69)\end{array}$ & $\begin{array}{l}-0.068 \\
(0.74)\end{array}$ & $\begin{array}{c}-0.081^{* * *} \\
(0.00)\end{array}$ & $\begin{array}{l}-0.002 \\
(0.94)\end{array}$ & $\begin{array}{c}-0.023 \\
(0.50)\end{array}$ & $\begin{array}{l}0.034 \\
(0.89)\end{array}$ \\
\hline$\Delta e_{i j, t} \times\left(S_{j}^{\$}+S_{j}^{€}\right)$ & & & & $\begin{array}{l}0.059 \\
(0.80)\end{array}$ & & & & $\begin{array}{l}-0.029 \\
(0.92)\end{array}$ \\
\hline$\Delta e_{\$ j t}$ & & $\begin{array}{c}-0.180^{* * *} \\
(0.00)\end{array}$ & $\begin{array}{c}-0.278^{* * *} \\
(0.00)\end{array}$ & $\begin{array}{l}0.030 \\
(0.73)\end{array}$ & & $\begin{array}{c}-0.165^{* * *} \\
(0.00)\end{array}$ & $\begin{array}{c}-0.533^{* * *} \\
(0.00)\end{array}$ & $\begin{array}{c}-0.227^{* * *} \\
(0.00)\end{array}$ \\
\hline$\Delta e_{\$ j, t} \times S_{j}^{\$}$ & & & & $\begin{array}{c}-0.525^{* * *} \\
(0.00)\end{array}$ & & & & $\begin{array}{c}-0.416^{* * *} \\
(0.00)\end{array}$ \\
\hline$\Delta e_{€ j, t}$ & & & $\begin{array}{l}-0.047 \\
(0.46)\end{array}$ & $\begin{array}{r}-0.037 \\
(0.64)\end{array}$ & & & $\begin{array}{c}0.318^{* * *} \\
(0.00)\end{array}$ & $\begin{array}{l}0.134 \\
(0.12)\end{array}$ \\
\hline$\Delta e_{€ j, t} \times S_{j}^{€}$ & & & & $\begin{array}{c}-0.411^{* *} \\
(0.01)\end{array}$ & & & & $\begin{array}{l}-0.229 \\
(0.16)\end{array}$ \\
\hline Observations & 58,585 & 58,585 & 43,621 & 37,750 & 58,585 & 58,585 & 43,621 & 37,750 \\
\hline R-squared & 0.061 & 0.062 & 0.058 & 0.063 & 0.147 & 0.154 & 0.153 & 0.176 \\
\hline Dyads & 2,847 & 2,847 & 2,847 & 2,446 & 2,847 & 2,847 & 2,847 & 2,446 \\
\hline
\end{tabular}

Notes: The first (last) four columns present unweighted (trade-weighted) regressions. All regressions include two $\Delta$ ER and importer's $\Delta$ GDP lags and dyad fixed effects. Columns (1)-(2) and (5)-(6) include time fixed effects, and columns (3)-(4) and (7)-(8) include global controls. Standard errors clustered by dyad. p-values in parentheses. ${ }^{* * *} \mathrm{p}<0.01$, ** $\mathrm{p}<0.05,{ }^{*} \mathrm{p}<0.1$. 


\section{Conclusion}

Our paper provides the most comprehensive and up-to-date panel data set on invoicing currency patterns in international trade. The richness of the information available in the data allowed us to establish several novel stylised facts of relevance to theory and economic policy; examples include rapid and sudden changes in international trade invoicing currency patterns in some European countries and the regionally dominant role of the euro outside of Europe in parts of Africa. In addition, these data allowed us to confirm findings from earlier research regarding the globally dominant role of the US dollar in invoicing and the overall stability of invoicing currency patterns.

In order to illustrate the usefulness of the data set, we followed the literature and studied the role of vehicle currency invoicing for exchange rate pass-through to import prices and trade volumes. This exercise confirmed the findings of the earlier literature that countries invoicing more in US dollars (euros) tend to experience greater US dollar (euro) exchange rate pass-through to their import prices; also, their trade volumes are more sensitive to fluctuations in these exchange rates. However, the data is intended to foster additional research in many areas of open-economy macroeconomics. For example, the data set can help explore the relationship between invoicing currencies and the effects of exchange rate movements, deepening trade integration or the prominence of global value chains, as well as the role of international currencies, the conduct of monetary policy and international spillovers, which could prove more demanding in a post-COVID-19 world.

\section{References}

Adler, G., Casas, C., Cubeddu, L., Gopinath, G., Li, N., Meleshchuk, S., OsorioBuitron, C., Puy, D., Timmer, Y., 2020. Dominant currencies and external adjustment. IMF Staff Discussion Note.

Bacchetta, P., van Wincoop, E., 2005. A Theory of the Currency Denomination of International Trade. Journal of International Economics 67, 295-319.

Bahaj, S., Reis, R., 2020. Jumpstarting an International Currency. CEPR Discussion Paper 14793.

Burstein, A., Gopinath, G., 2014. International Prices and Exchange Rates. Handbook of International Economics 4, 391-451.

Committee on the Global Financial System, 2014. Trade Finance: Developments and Issues. Bank for International Settlements . 
Devereux, M., Dong, W., Tomlin, B., 2017. Importers and Exporters in Exchange Rate Pass-through and Currency Invoicing. Journal of International Economics 105, $187-204$.

Devereux, M., Shi, S., 2013. Vehicle Currency. International Economic Review 54, 97-133.

European Central Bank, 2019. The International Role of the Euro. European Central Bank, Frankfurt.

Goldberg, L., Tille, C., 2008. Vehicle-currency Use in International Trade. Journal of International Economics 76, 177-192.

Gopinath, G., 2015. The International Price System. NBER Working Paper 21646.

Gopinath, G., Casas, C., Diez, F., Gourinchas, P.O., Plagborg-Moller, M., 2020. Dominant Currency Paradigm. American Economic Review 110, 677-719.

Gopinath, G., Itskhoki, O., Rigobon, R., 2010. Currency Choice and Exchange Rate Pass-Through. American Economic Review 100, 304-336.

Gopinath, G., Stein, J., 2018. Banking, Trade, and the Making of a Dominant Currency. NBER Working Paper 24485.

Ito, H., Chinn, M., 2014. The Rise of the "Redback" and the People's Republic of China's Capital Account Liberalization: An Empirical Analysis of the Determinants of Invoicing Currencies. ADBI Working Paper 473.

Kamps, A., 2006. The Euro as Invoicing Currency in International Trade. ECB Working Paper 665.

Lafarguette, R., 2015. Update of Kamps (2006). ECB mimeo .

Mukhin, D., 2018. An Equilibrium Model of the International Price System. mimeo .

Murray, J., Powell, J., 2002. Dollarization in Canada: The Buck Stops There. Bank of Canada Technical Report 90.

Portes, R., Rey, H., 1998. The Emergence of the Euro as an International Currency. Economic Policy 13, 305-343.

Rey, H., 2001. International Trade and Currency Exchange. Review of Economic Studies 68, 443-464.

Schmidt-Eisenlohr, T., 2013. Towards a Theory of Trade Finance. Journal of International Economics 91, 96-112. 


\section{A Additional tables}

\section{Table A.1: Invoicing currency data overview}

\begin{tabular}{|c|c|c|c|c|c|}
\hline Country & Code & Range & Type & Source & Comment \\
\hline \multicolumn{6}{|l|}{ North Africa } \\
\hline Algeria & DZA & 2001-10 & invoicing & Customs Authority & $\begin{array}{l}\text { Exports only for 2003-04; } \\
2001 \text { for euro not avail- } \\
\text { able due to lack of legacy } \\
\text { currency information from } \\
\text { Lafarguette (2015) (2003- } \\
2004 \text { Exports; Imports: } \\
2001-2010)\end{array}$ \\
\hline Egypt & EGY & 2010-19 & invoicing & Central Bank of Egypt & \\
\hline Morocco & MAR & $2006-16$ & invoicing & $\begin{array}{l}\text { Ministry of Planning and } \\
\text { Economics }\end{array}$ & \\
\hline Tunisia & TUN & $\begin{array}{l}1995-2001, \quad 2010- \\
19\end{array}$ & invoicing & $\begin{array}{l}\text { Banque Centrale de } \\
\text { Tunisie }\end{array}$ & $\begin{array}{l}1995-2001 \text { from Kamps } \\
(2006) \text {, US dollar data } \\
\text { until 2018, euro data until } \\
2019\end{array}$ \\
\hline \multicolumn{6}{|l|}{ Sub-Saharan Africa } \\
\hline Angola & AGO & 2016-19 & invoicing & National Bank of Angola & \\
\hline Benin & BEN & 2016-19 & invoicing & $\begin{array}{l}\text { Central Bank of West } \\
\text { African Currency Union }\end{array}$ & $\begin{array}{l}\text { Data part of the West } \\
\text { African Currency Union } \\
\text { aggregate excluding Cote } \\
\text { d'Ivoire and Senegal }\end{array}$ \\
\hline Botswana & BWA & 2003-19 & invoicing & Statistics Botswana & \\
\hline Burkina Faso & BFA & 2016-19 & invoicing & $\begin{array}{l}\text { Central Bank of West } \\
\text { African Currency Union }\end{array}$ & $\begin{array}{l}\text { Data part of the West } \\
\text { African Currency Union } \\
\text { aggregate excluding Cote } \\
\text { d'Ivoire and Senegal }\end{array}$ \\
\hline Cote d'Ivoire & CIV & 2016-19 & invoicing & $\begin{array}{l}\text { Central Bank of West } \\
\text { African Currency Union }\end{array}$ & \\
\hline Eswatini & SWZ & $2016-18$ & invoicing & Central Bank of Eswatini & \\
\hline Ghana & GHA & 2018-19 & settlement & Bank of Ghana & \\
\hline Guinea-Bissau & GNB & 2016-19 & invoicing & $\begin{array}{l}\text { Central Bank of West } \\
\text { African Currency Union }\end{array}$ & $\begin{array}{l}\text { Data part of the West } \\
\text { African Currency Union } \\
\text { aggregate excluding Cote } \\
\text { d'Ivoire and Senegal }\end{array}$ \\
\hline Liberia & LBR & $2000-19$ & invoicing & Central Bank of Liberia & $\begin{array}{l}\text { Liberian trade invoiced ex- } \\
\text { clusively in US dollars ac- } \\
\text { cording to Central Bank of } \\
\text { Liberia. We assume such } \\
\text { practice has been the case } \\
\text { since } 2000\end{array}$ \\
\hline Madagascar & MDG & $2015-18$ & invoicing & $\begin{array}{l}\text { Banque Centrale de Mada- } \\
\text { gascar }\end{array}$ & \\
\hline Malawi & MWI & 2014-19 & settlement & Reserve Bank of Malawi & \\
\hline Mali & MLI & 2016-19 & invoicing & $\begin{array}{l}\text { Central Bank of West } \\
\text { African Currency Union }\end{array}$ & $\begin{array}{l}\text { Data part of the West } \\
\text { African Currency Union } \\
\text { aggregate excluding Cote } \\
\text { d'Ivoire and Senegal }\end{array}$ \\
\hline Mauritius & MUS & 2009-19 & invoicing & Bank of Mauritius & \\
\hline Niger & NER & 2016-19 & invoicing & $\begin{array}{l}\text { Central Bank of West } \\
\text { African Currency Union }\end{array}$ & $\begin{array}{l}\text { Data part of the West } \\
\text { African Currency Union } \\
\text { aggregate excluding Cote } \\
\text { d'Ivoire and Senegal }\end{array}$ \\
\hline Senegal & SEN & 2016-19 & invoicing & $\begin{array}{l}\text { Central Bank of West } \\
\text { African Currency Union }\end{array}$ & \\
\hline Seychelles & SYC & 2015-19 & invoicing & Central Bank of Seychelles & Only imports \\
\hline South Africa & $\mathrm{ZAF}$ & 2003 & invoicing & South Africa Treasury & $\begin{array}{l}\text { From Kamps (2006); only } \\
\text { exports }\end{array}$ \\
\hline Tanzania & TZA & 2015-19 & invoicing & Bank of Tanzania & \\
\hline Togo & TGO & 2016-19 & invoicing & $\begin{array}{l}\text { Central Bank of West } \\
\text { African Currency Union }\end{array}$ & $\begin{array}{l}\text { Data part of the West } \\
\text { African Currency Union } \\
\text { aggregate excluding Cote } \\
\text { d'Ivoire and Senegal }\end{array}$ \\
\hline Central Asia & & & & & \\
\hline Armenia & $\mathrm{ARM}$ & 2015-19 & invoicing & $\begin{array}{l}\text { Armenia State Revenue } \\
\text { Commitee }\end{array}$ & \\
\hline Azerbaijan & AZE & $2012-18$ & invoicing & $\begin{array}{l}\text { Central Bank of Azerbai- } \\
\text { jan }\end{array}$ & \\
\hline
\end{tabular}

Note: "A1" refers to trade with the rest of the world, "J6" to trade with non-euro area countries, and "V2" to trade with non-EU countries. When data for more than one concept is available for the same time period, priority is given to the A1 series, followed by the J6 series and lastly the V2 series. In these cases, J6 and V2 series are adjusted to refer to trade with the rest of the world assuming that a certain share of intra-EU and intra-euro area trade is invoiced imepros, typically $90 \%$ for euro area countries and $60 \%$ for non-euro area $E U$ countries. When data are available for different concepts for different, non-overlapping time periods, we perform "continuationadjustment". In particular, we adjust the V2/J6 series by assuming a euro invoicing share for intra-EU trade such that the transition between the time series is smooth. Finally, when data are available for overlapping time periods but also cover different sub-periods we backpolate and extrapolate based on actual changes, again giving priority to A1, J6 and then V2.

\section{CInternational Monetary Fund. Not for Redistribution}


Table A.1: Invoicing currency data overview (continued)

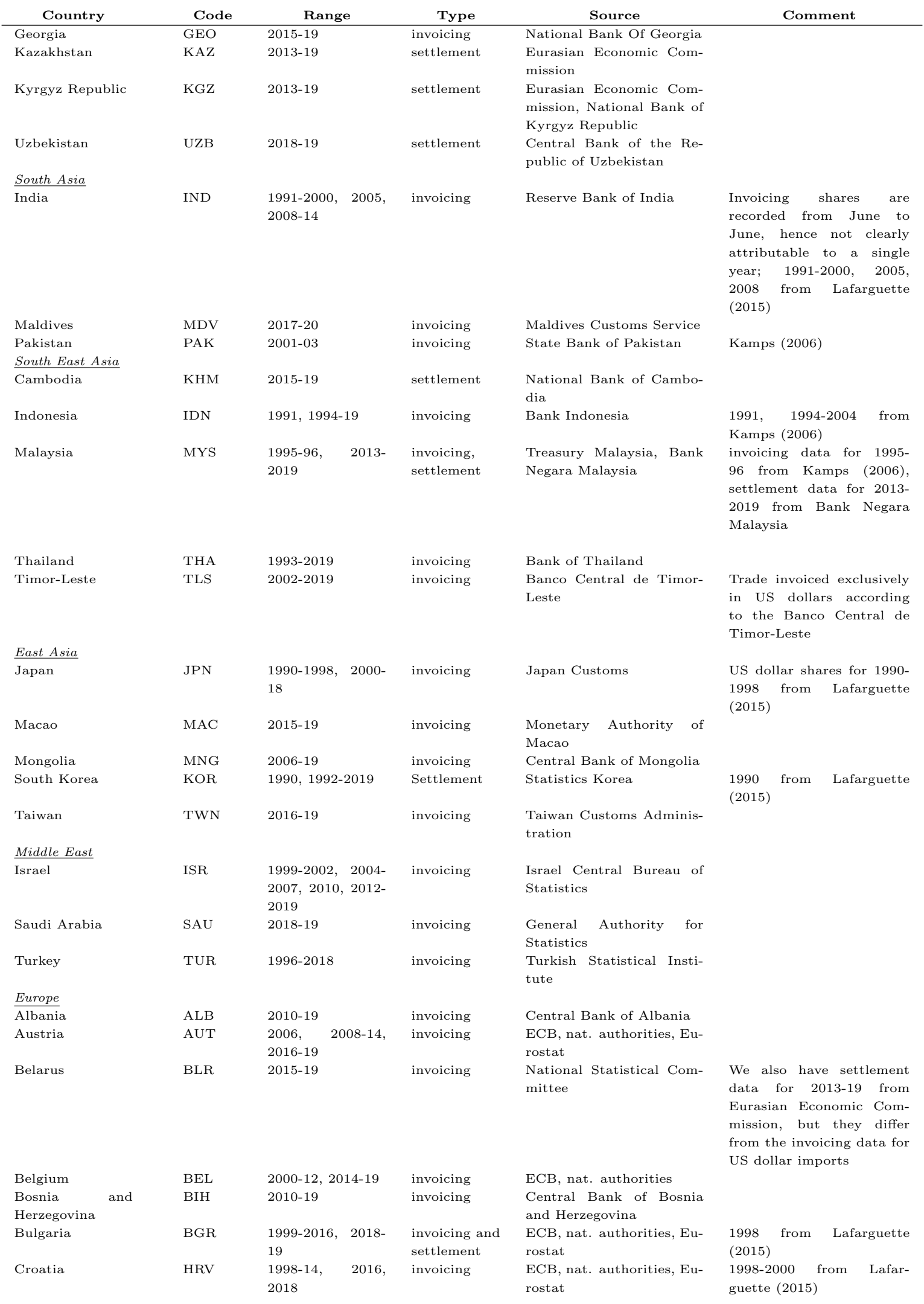

Note: "A1" refers to trade with the rest of the world, "J6" to trade with non-euro area countries, and "V2" to trade with non-EU countries. When data for more than one concept is available for the same time period, priority is given to the A1 series, followed by the $J 6$ series and lastly the V2 series. In these cases, J6 and V2 series are adjusted to refer to trade with the rest of the world assuming that a certain share of intra-EU and intra-euro area trade is invoiced in euros, typically $90 \%$ for euro area countries and $60 \%$ for non-euro area EU countries. When data are available for different concepts forg different, non-overlapping time periods, we perform "continuationadjustment". In particular, we adjust the V2/J6 series by assuming a euro invoicing share for intra-EU trade such that the transition between the time series is smooth. Finally, when data are available for overlapping time periods but also cover different sub-periods we

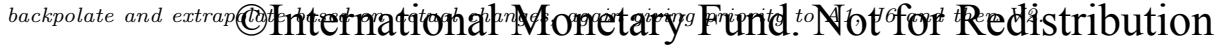


Table A.1: Invoicing currency data overview (continued)

\begin{tabular}{|c|c|c|c|c|c|}
\hline Country & Code & Range & Type & Source & Comment \\
\hline Cyprus & CYP & 2003-14, 2016-19 & invoicing & $\begin{array}{l}\mathrm{ECB}, \text { nat. authorities, Eu- } \\
\text { rostat }\end{array}$ & \\
\hline Czech Republic & $\mathrm{CZE}$ & 1999-2019 & invoicing & ECB, nat. authorities & \\
\hline Denmark & DNK & $\begin{array}{l}1999-2004,2010, \\
2012,2014,2016, \\
2018\end{array}$ & invoicing & $\begin{array}{l}\mathrm{ECB} \text {, nat. authorities, Eu- } \\
\text { rostat }\end{array}$ & \\
\hline Estonia & $\mathrm{EST}$ & $\begin{array}{l}1999-2014, \quad 2016- \\
19\end{array}$ & invoicing & $\begin{array}{l}\mathrm{ECB} \text {, nat. authorities, Eu- } \\
\text { rostat }\end{array}$ & \\
\hline Finland & FIN & $\begin{array}{l}2006,2010,2012 \\
2014,2016-19\end{array}$ & invoicing & $\begin{array}{l}\mathrm{ECB} \text {, nat. authorities, Eu- } \\
\text { rostat }\end{array}$ & \\
\hline France & FRA & $1999-2019$ & invoicing & ECB, nat. authorities & \\
\hline Germany & DEU & 2002-07, 2009-19 & invoicing & $\begin{array}{l}\mathrm{ECB} \text {, nat. authorities, Eu- } \\
\text { rostat }\end{array}$ & \\
\hline Greece & GRC & 2001-19 & invoicing & ECB, nat. authorities & \\
\hline Hungary & HUN & $\begin{array}{l}1992-2014, \quad 2016- \\
19\end{array}$ & invoicing & ECB, nat. authorities & \\
\hline Iceland & ISL & $1998-2019$ & invoicing & Statistics Iceland & \\
\hline Ireland & IRL & 2006-14, 2016-19 & invoicing & $\begin{array}{l}\mathrm{ECB} \text {, nat. authorities, Eu- } \\
\text { rostat }\end{array}$ & \\
\hline Italy & ITA & $\begin{array}{l}2001-12, \quad 2014, \\
2016\end{array}$ & $\begin{array}{l}\text { settlement } \\
\text { before } 2010, \\
\text { invoicing } \\
\text { after } 2010\end{array}$ & $\begin{array}{l}\mathrm{ECB} \text {, nat. authorities, Eu- } \\
\text { rostat }\end{array}$ & \\
\hline Latvia & LVA & 2000-19 & invoicing & ECB, nat. authorities & \\
\hline Lithuania & LTU & 1999-2019 & invoicing & ECB, nat. authorities & \\
\hline Luxembourg & LUX & 2000-14, 2016-19 & invoicing & $\begin{array}{l}\mathrm{ECB} \text {, nat. authorities, Eu- } \\
\text { rostat }\end{array}$ & \\
\hline Malta & MLT & $\begin{array}{l}2010,2012,2014 \\
2016,2018-19\end{array}$ & invoicing & Eurostat & \\
\hline Moldova & MDA & $2017-18$ & invoicing & National Bank of Moldova & $\begin{array}{l}\text { We also have settlement } \\
\text { data for 2014- } 18 \text { from Na- } \\
\text { tional Bank of Moldova, } \\
\text { but they differ from the in- } \\
\text { voicing data for US dollar } \\
\text { and euro exports }\end{array}$ \\
\hline Montenegro & MNE & 2010-19 & settlement & $\begin{array}{l}\text { Central Bank of Montene- } \\
\text { gro }\end{array}$ & \\
\hline Netherlands & NLD & $\begin{array}{l}1998-2002, \quad 2006, \\
2010,2012,2014, \\
2016,2018-19\end{array}$ & invoicing & $\begin{array}{l}\mathrm{ECB} \text {, nat. authorities, Eu- } \\
\text { rostat }\end{array}$ & \\
\hline $\begin{array}{l}\text { Northern Mace- } \\
\text { donia }\end{array}$ & MKD & $1998-17$ & invoicing & State Statistical Office & $\begin{array}{l}\text { 1998-2001 from Kamps } \\
(2006), \quad 2002-2012 \text { from } \\
\text { Lafarguette }(2015)\end{array}$ \\
\hline Norway & NOR & $1999-18$ & invoicing & Statistics Norway & \\
\hline Poland & POL & $\begin{array}{l}1994-2010, \quad 2012 \\
2014,2016-19\end{array}$ & invoicing & $\begin{array}{l}\mathrm{ECB} \text {, nat. authorities, Eu- } \\
\text { rostat }\end{array}$ & \\
\hline Portugal & PRT & 2000-19 & invoicing & ECB, nat. authorities & \\
\hline Romania & $\mathrm{ROU}$ & $1999-2019$ & invoicing & ECB, nat. authorities & \\
\hline Russia & RUS & 2008-19 & settlement & Central Bank of Russia & \\
\hline Serbia & SRB & 2002-03, 2007-19 & invoicing & National Bank of Serbia & $\begin{array}{l}\text { 2002-03 from Lafarguette } \\
(2015)\end{array}$ \\
\hline Slovenia & SVN & $\begin{array}{l}2000-01,2003-14, \\
2016-19\end{array}$ & invoicing & $\begin{array}{l}\mathrm{ECB} \text {, nat. authorities, Eu- } \\
\text { rostat }\end{array}$ & \\
\hline Slovakia & SVK & 1999-2019 & invoicing & ECB, nat. authorities & \\
\hline Spain & $\mathrm{ESP}$ & $\begin{array}{l}1998-2014, \quad 2016- \\
18\end{array}$ & invoicing & $\begin{array}{l}\mathrm{ECB} \text {, nat. authorities, Eu- } \\
\text { rostat }\end{array}$ & \\
\hline Sweden & SWE & 2010-19 & invoicing & ECB, nat. authorities & \\
\hline Switzerland & $\mathrm{CHE}$ & $2012-18$ & invoicing & $\begin{array}{l}\text { Federal Customs Adminis- } \\
\text { tration }\end{array}$ & \\
\hline Ukraine & UKR & 2001-04, 2006-19 & settlement & National Bank of Ukraine & $\begin{array}{l}\text { 2001-04 taken from Lafar- } \\
\text { guette (2015); we also have } \\
\text { invoicing data for 2015-19 } \\
\text { from State Customs Ser- } \\
\text { vice of Ukraine }\end{array}$ \\
\hline United Kingdom & GBR & $\begin{array}{l}1999-2002, \quad 2010- \\
18\end{array}$ & invoicing & $\begin{array}{l}\text { ECB, nat. authorities, } \\
\text { Eurostat, HM Revenue \& } \\
\text { Customs }\end{array}$ & \\
\hline \multicolumn{6}{|l|}{$\underline{O c e a n i a}$} \\
\hline Australia & AUS & $1997-2016$ & invoicing & $\begin{array}{l}\text { Australian Bureau of } \\
\text { Statistics }\end{array}$ & \\
\hline
\end{tabular}

Note: "A1" refers to trade with the rest of the world, "J6" to trade with non-euro area countries, and "V2" to trade with non-EU countries. When data for more than one concept is available for the same time period, priority is given to the A1 series, followed by the J6 series and lastly the V2 series. In these cases, J6 and V2 series are adjusted to refer to trade with the rest of the world assuming that a certain share of intra-EU and intra-euro area trade is invoiced in euros, typically $90 \%$ for euro area countries and $60 \%$ for non-euro area EU countries. When data are available for different concepts foy fifferent, non-overlapping time periods, we perform "continuationadjustment". In particular, we adjust the V2/J6 series by assuming 3 euro invoicing share for intra-EU trade such that the transition between the time series is smooth. Finally, when data are available for overlapping time periods but also cover different sub-periods we

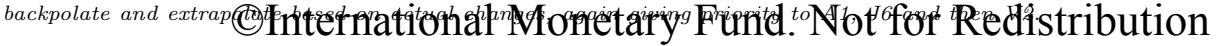


Table A.1: Invoicing currency data overview (continued)

\begin{tabular}{|c|c|c|c|c|c|}
\hline Country & Code & Range & Type & Source & Comment \\
\hline Fiji & FJI & 2016-19 & invoicing & $\begin{array}{l}\text { Fiji Revenue and Customs } \\
\text { Services }\end{array}$ & \\
\hline New Zealand & NZL & 2004-19 & invoicing & Stats NZ & \\
\hline Solomon Islands & SLB & 2015-19 & settlement & $\begin{array}{l}\text { Central Bank of Solomon } \\
\text { Islands }\end{array}$ & Only US dollar \\
\hline \multicolumn{6}{|c|}{$\underline{\text { Latin America and Caribbean }}$} \\
\hline Argentina & ARG & 2010-19 & invoicing & $\begin{array}{l}\text { National Institute of } \\
\text { Statistics and Census }\end{array}$ & \\
\hline Bahamas & BHS & 2009-18 & invoicing & $\begin{array}{l}\text { Central Bank of The Ba- } \\
\text { hamas }\end{array}$ & \\
\hline Brazil & BRA & $2000-12,2017-18$ & $\begin{array}{l}\text { settlement, } \\
\text { invoicing }\end{array}$ & $\begin{array}{l}\text { Banco Central do Brasil, } \\
\text { Ministry of Foreign Trade }\end{array}$ & $\begin{array}{l}\text { Data for } 2000-12 \text { from La- } \\
\text { farguette }(2015)\end{array}$ \\
\hline Chile & CHL & 2004-19 & invoicing & Chile Customs & \\
\hline Colombia & $\mathrm{COL}$ & $2007-18$ & invoicing & Banco de la República & Exports only \\
\hline Costa Rica & CRI & 2005-19 & invoicing & $\begin{array}{l}\text { Banco Central de Costa } \\
\text { Rica, Direccion General de } \\
\text { Aduanas }\end{array}$ & \\
\hline Ecuador & $\mathrm{ECU}$ & 2015-19 & invoicing & $\begin{array}{l}\text { Banco Central del } \\
\text { Ecuador, National Cus- } \\
\text { toms Service of Ecuador }\end{array}$ & \\
\hline Paraguay & PRY & 2014-2020 & invoicing & Customs & \\
\hline Peru & PER & $2009-18$ & invoicing & $\begin{array}{l}\text { Banco Central de Reserva } \\
\text { del Peru }\end{array}$ & Only imports \\
\hline Suriname & SUR & 2015-19 & invoicing & Central Bank of Suriname & \\
\hline Uruguay & URY & 2015-19 & invoicing & $\begin{array}{l}\text { Customs Authority of } \\
\text { Uruguay }\end{array}$ & \\
\hline \multicolumn{6}{|l|}{ North America } \\
\hline Canada & CAN & 2001 & invoicing & Murray and Powell (2002) & $\begin{array}{l}\text { from Kamps (2006), only } \\
\text { US dollar exports }\end{array}$ \\
\hline United States & USA & $2003-18$ & invoicing & $\begin{array}{l}\text { Bureau of Labour Statis- } \\
\text { tics }\end{array}$ & \\
\hline \multicolumn{6}{|c|}{$\begin{array}{l}\text { Note: "A1" refers to trade with the rest of the world, "J6" to trade with non-euro area countries, and "V2" to trade with non-EU } \\
\text { countries. When data for more than one concept is available for the same time period, priority is given to the A1 series, followed by the } \\
\text { J6 series and lastly the V2 series. In these cases, J6 and V2 series are adjusted to refer to trade with the rest of the world assuming that } \\
\text { a certain share of intra-EU and intra-euro area trade is invoiced in euros, typically } 90 \% \text { for euro area countries and } 60 \% \text { for non-euro } \\
\text { area EU countries. When data are available for different concepts for different, non-overlapping time periods, we perform "continuation- } \\
\text { adjustment". In particular, we adjust the V2/J6 series by assuming a euro invoicing share for intra-EU trade such that the transition } \\
\text { between the time series is smooth. Finally, when data are available for overlapping time periods but also cover different sub-periods we } \\
\text { backpolate and extrapolate based on actual changes, again giving priority to A1, J6 and then V2. }\end{array}$} \\
\hline
\end{tabular}


Table A.2: Exchange Rate Pass-Through into Import Prices:

Subsample of Non-Dollar, Euro or Pegged Economies

\begin{tabular}{lcccccc}
\hline & $(1)$ & $(2)$ & $(3)$ & $(4)$ & $(5)$ & $(6)$ \\
& $\Delta p_{i j, t}$ & $\Delta p_{i j, t}$ & $\Delta p_{i j, t}$ & $\Delta p_{i j, t}$ & $\Delta p_{i j, t}$ & $\Delta p_{i j, t}$ \\
\hline$\Delta e_{i j, t}$ & $0.792^{* * *}$ & $0.162^{* * *}$ & $0.281^{* * *}$ & $0.841^{* * *}$ & $0.359^{* * *}$ & $0.401^{* * *}$ \\
& $(0.00)$ & $(0.00)$ & $(0.00)$ & $(0.00)$ & $(0.00)$ & $(0.00)$ \\
$\Delta e_{i j, t} \times S_{j}^{\$}$ & & & $-0.173^{* * *}$ & & & $-0.115^{*}$ \\
& & & $(0.00)$ & & & $(0.09)$ \\
$\Delta e_{\$ j, t}$ & & $0.805^{* * *}$ & $0.651^{* * *}$ & & $0.620^{* * *}$ & $0.379^{* * *}$ \\
& & $(0.00)$ & $(0.00)$ & & $(0.00)$ & $(0.00)$ \\
$\Delta e_{\$ j, t} \times S_{j}^{\$}$ & & & $0.241^{* * *}$ & & & $0.393^{* * *}$ \\
& & & $(0.00)$ & & & $(0.00)$ \\
\hline Observations & 34,304 & 34,304 & 28,948 & 34,304 & 34,304 & 28,948 \\
R-squared & 0.382 & 0.421 & 0.476 & 0.352 & 0.376 & 0.605 \\
Dyads & 1,741 & 1,741 & 1,449 & 1,741 & 1,741 & 1,449 \\
\hline \multicolumn{2}{c}{ Notes: The firt }
\end{tabular}

Notes: The first (last) three columns present unweighted (trade-weighted) regressions. All regressions include two $\triangle \mathrm{ER}$ and $\triangle \mathrm{PPI}$ lags, and time and dyad fixed effects. Standard errors clustered by dyad. p-values in parentheses. $* * * \mathrm{p}<0.01,{ }^{* *} \mathrm{p}<0.05,{ }^{*} \mathrm{p}<0.1$. 
Table A.3: Dollar vs. Euro Exchange Rate Pass-Through into Prices: Subsample of Non-Dollar, Euro or Pegged Economies

\begin{tabular}{lcccccc}
\hline & $(1)$ & $(2)$ & $(3)$ & $(4)$ & $(5)$ & $(6)$ \\
& $\Delta p_{i j, t}$ & $\Delta p_{i j, t}$ & $\Delta p_{i j, t}$ & $\Delta p_{i j, t}$ & $\Delta p_{i j, t}$ & $\Delta p_{i j, t}$ \\
\hline$\Delta e_{i j, t}$ & $0.369^{* * *}$ & $0.195^{* * *}$ & $0.604^{* * *}$ & $0.587^{* * *}$ & $0.400^{* * *}$ & $0.442^{* *}$ \\
$\Delta e_{i j, t} \times\left(S_{j}^{\$}+S_{j}^{€}\right)$ & $(0.00)$ & $(0.00)$ & $(0.00)$ & $(0.00)$ & $(0.00)$ & $(0.04)$ \\
$\Delta e_{\$ j t}$ & & & $-0.466^{* * *}$ & & & -0.125 \\
& & & $(0.00)$ & & & $(0.58)$ \\
$\Delta e_{\$ j, t} \times S_{j}^{\$}$ & & $0.964^{* * *}$ & $0.642^{* * *}$ & & $0.917^{* * *}$ & $0.396^{* * *}$ \\
& & $(0.00)$ & $(0.00)$ & & $(0.00)$ & $(0.00)$ \\
$\Delta e_{€_{j, t}}$ & & & $0.452^{* * *}$ & & & $0.677^{* * *}$ \\
$\Delta e_{€ j, t} \times S_{j}^{€}$ & $0.419^{* * *}$ & $-0.237^{* * *}$ & $-0.284^{* * *}$ & 0.091 & $-0.489^{* *}$ & $-0.371^{* *}$ \\
& $(0.00)$ & $(0.00)$ & $(0.00)$ & $(0.53)$ & $(0.02)$ & $(0.03)$ \\
& & & $0.584^{* * *}$ & & & $0.579^{* *}$ \\
Observations & & & $(0.00)$ & & & $(0.01)$ \\
R-squared & 25,217 & 25,217 & 20,945 & 25,217 & 25,217 & 20,945 \\
Dyads & 0.146 & 0.166 & 0.207 & 0.111 & 0.130 & 0.303 \\
\hline
\end{tabular}

Notes: The first (last) three columns present unweighted (trade-weighted) regressions. All regressions include two $\Delta \mathrm{ER}$ and $\Delta \mathrm{PPI}$ lags, dyad fixed effects and global controls. Standard errors clustered by dyad. p-values in parentheses. ${ }^{* * *} \mathrm{p}<0.01,{ }^{* *} \mathrm{p}<0.05,{ }^{*} \mathrm{p}<0.1$. 
Table A.4: Trade Elasticity with respect to Exchange Rates:

Subsample of Non-Dollar, Euro or Pegged Economies

\begin{tabular}{lcccccccc}
\hline & $(1)$ & $(2)$ & $(3)$ & $(4)$ & $(5)$ & $(6)$ & $(7)$ & $(8)$ \\
& $\Delta y_{i j, t}$ & $\Delta y_{i j, t}$ & $\Delta y_{i j, t}$ & $\Delta y_{i j, t}$ & $\Delta y_{i j, t}$ & $\Delta y_{i j, t}$ & $\Delta y_{i j, t}$ & $\Delta y_{i j, t}$ \\
\hline$\Delta e_{i j, t}$ & $-0.115^{* * *}$ & -0.034 & -0.025 & -0.117 & $-0.091^{* * *}$ & -0.008 & -0.045 & 0.175 \\
& $(0.00)$ & $(0.13)$ & $(0.64)$ & $(0.60)$ & $(0.00)$ & $(0.82)$ & $(0.25)$ & $(0.36)$ \\
$\Delta e_{i j, t} \times\left(S_{j}^{\$}+S_{j}^{€}\right)$ & & & & 0.103 & & & -0.229 \\
& & & & $(0.71)$ & & $(0.30)$ \\
$\Delta e_{\$ j t}$ & & $-0.155^{* * *}$ & $-0.685^{* * *}$ & $-0.257^{* *}$ & & $-0.142^{* * *}$ & $-0.723^{* * *}$ & $-0.226^{*}$ \\
& & $(0.00)$ & $(0.00)$ & $(0.05)$ & & $(0.00)$ & $(0.00)$ & $(0.08)$ \\
$\Delta e_{\$ j, t} \times S_{j}^{\$}$ & & & & $-0.364^{* *}$ & & & $-0.414^{* *}$ \\
& & & & $(0.02)$ & & & & $(0.03)$ \\
$\Delta e_{€ j, t}$ & & & $0.315^{* * *}$ & 0.130 & & & $0.551^{* * *}$ & $0.252^{*}$ \\
& & & $(0.00)$ & $(0.18)$ & & & $(0.00)$ & $(0.08)$ \\
$\Delta e_{€ j, t} \times S_{j}^{€}$ & & & & -0.090 & & & $-0.474^{* *}$ \\
& & & & $(0.65)$ & & & $(0.01)$ \\
\hline Observations & 36,353 & 36,353 & 26,898 & 22,348 & 36,353 & 36,353 & 26,898 & 22,348 \\
R-squared & 0.074 & 0.076 & 0.073 & 0.080 & 0.159 & 0.165 & 0.169 & 0.209 \\
Dyads & 1,755 & 1,755 & 1,755 & 1,452 & 1,755 & 1,755 & 1,755 & 1,452 \\
\hline
\end{tabular}

Notes: The first (last) four columns present unweighted (trade-weighted) regressions. All regressions include two $\Delta$ ER and importer's $\Delta$ GDP lags and dyad fixed effects. Columns (1)-(2) and (5)-(6) include time fixed effects, and columns $(3)-(4)$ and $(7)-(8)$ include global controls. Standard errors clustered by dyad. p-values in parentheses. $* * * \mathrm{p}<0.01$, ** $\mathrm{p}<0.05,{ }^{*} \mathrm{p}<0.1$ 


\section{B Additional figures}

Figure B.1: Comparison of invoicing and settlement data
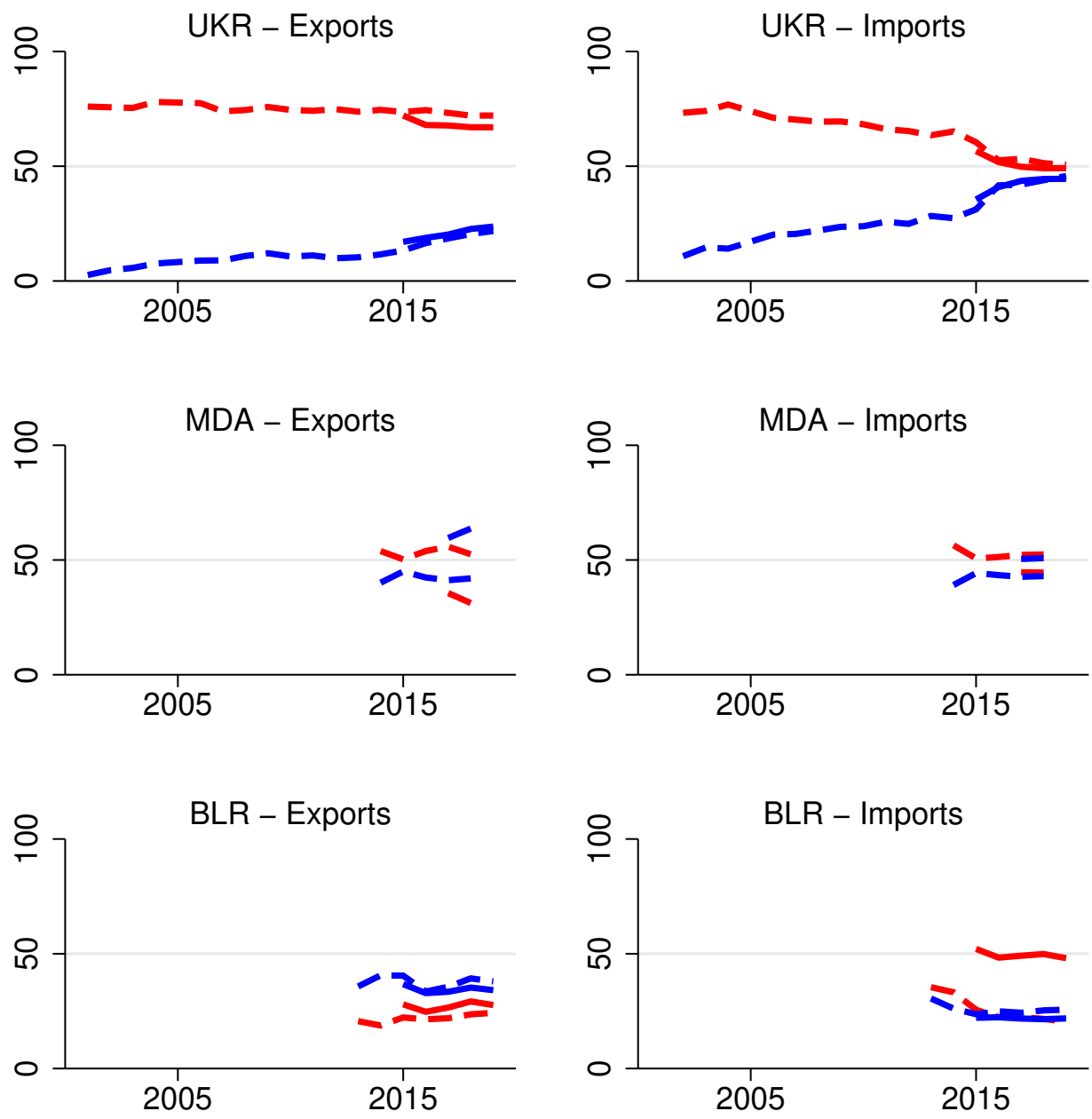

\section{USD invoicing EUR invoicing}

Note: The panels compare data for invoicing and settlement currency in exports for selected countries for which both series are available. Invoicing data are depicted by solid lines, while settlement data by dashed lines. Data for the US dollar are depicted in red, while data for the euro are depicted in blue. 